\title{
Identification of Caribbean basin hurricanes from Spanish documentary sources
}

\author{
Ricardo García-Herrera • Luis Gimeno • Pedro Ribera • \\ Emiliano Hernández • Ester González • \\ Guadalupe Fernández
}

Received: 9 September 2005 / Accepted: 31 March 2006 / Published online: 16 March 2007

(C) Springer Science + Business Media B.V. 2007

\begin{abstract}
This paper analyses five hurricanes that occurred in the period 1600 to 1800 . These examples were identified during a systematic search in the General Archive of the Indies (AGI) in Seville. The research combined the expertise of climatologists and historians in order to optimise the search and analysis strategies. Results demonstrate the potential of this archive for the assessment of hurricanes in this period and show some of the difficulties involved in the collection of evidence of hurricane activity. The documents provide detailed descriptions of a hurricane's impacts and allow us to identify previously unreported hurricanes, obtain more precise dates for hurricanes previously identified, better define the area affected by a given hurricane and, finally, better assess a hurricane's intensity.
\end{abstract}

\section{Introduction}

Early Spanish documents provide interesting evidence regarding the occurrence of hurricanes in the Atlantic. As reported by Millás (1968), the first reported hurricane in the Caribbean basin occurred on June 25th 1494 at Isabella, Santo Domingo. The Spanish were soon familiar with these phenomena. In fact, according to the outstanding Cuban anthropologist, R. Ortiz (1984), Columbus arrived in Hispaniola on June 29th 1502 but was not allowed to dock by the Governor although he claimed that he was in danger from an approaching storm. He also advised the authorities that the fleet, ready to depart for Spain, should not leave port.

\footnotetext{
R. García-Herrera

Depto. Física de la Tierra II, Facultad de Ciencias Físicas, Universidad Complutense de Madrid, Ciudad Universitaria, 28040 Madrid, Spain

L. Gimeno

Universidad de Vigo

P. Ribera · E. González · G. Fernández

Universidad Pablo de Olavide

E. Hernández

Universidad Complutense de Madrid
} 
Nevertheless, the fleet left and was destroyed by a hurricane, whereas Columbus weathered the storm and survived. Ortiz suggests that Columbus learned about hurricane signs from the native seamen. One of the first detailed descriptions of a hurricane is provided by Fernández Oviedo (1535). He wrote two pages describing a hurricane that struck Hispaniola on August 3rd 1508, which are transcribed by Millás (1968):

'... Nearly at noon, that suddenly so much wind and water together commenced, and such an excessive amount of both of these things, that in this city of Santo Domingo all buhios or straw houses were demolished and even some (houses) of stone were greatly damaged. And in the same way, in many villages of this island the same thing happened, and on account of this cause, the country suffered very much, and all estates were destroyed. And the village called Buena Ventura (Good Luck), the hurricane demolished it to the level of the ground, and left her in such a way that it would be better to say Mala or Triste Ventura, or Derribada Ventura (Bad or Sad Luck or Destroyed Luck) for many that were destroyed in it. And what was more sorrowful was that in the harbour of this city more than twenty ships and caravels and other vessels were lost. ..'

The document continues by providing a description and the impacts of the hurricane. Oviedo provides more first hand descriptions in chapter III of book VI, [see case 6 of the 16th century in Millás (1968)] while in book L, chapter XXVII, yet more descriptions are included, but from indirect testimonies. Interestingly, in addition to the descriptions of single hurricanes, we also find references to extended periods of relative activity and inactivity on the part of hurricanes that may be considered evidence for the existence of multi-decadal variability in the 16th century similar to that observed in the modern hurricane records. Thus, according to B. de las Casas (1560) and Fernández Oviedo (1535), the hurricanes had ceased in Hispaniola once it had been Christianised (the island was conquered by the Spanish in 1495). Oviedo describes the situation as follows:

'it is thought by the devout Christians and is demonstrated by the experience that the hurricanes have ceased since the Holy Sacrament has been offered in all the churches and monasteries of this city and island...'

According to Ortiz, when the previously described intense hurricane of 1508 struck the islands, it was thought that it was due to God's rage, because the Indians said that hurricanes were very scarce before the Spanish had arrived. The latter, in turn, believed that it was due to their sins with the result that they started to build churches across the island. According to de las Casas (1560), the hurricanes were infrequent at the beginning of the conquest, but later they occurred:

'within recent times, every year and make ravages and destructions over sea and land .... and the causes are our new and abundant sins...'

Another proof of interdecadal variability is provided by the French Jesuit Du Tetre (1667) when describing the history of the French West Indies:

'... before, they occurred, I will say, every seven, or five years, but, since the West Indies were inhabited by Europeans they occur more frequently and usually after the end of July until mid-September'.

Some differences in the hurricanes seasonal cycle were also noted by Jesuit B. Viñes (1895), one of the outstanding names in the analysis and forecast of hurricanes in the Belen observatory of Havana, the ritual prayer Ad repellendas tempestates had been offered since 'immemorial times' in Puerto Rico to deter storms during August and September, while in Springer 
Cuba it was offered only in September and October, coinciding with the periods when the hurricanes were more likely to occur.

These few cases provide a small sample of the abundant information available on Atlantic hurricanes and contained in Spanish documents. Unfortunately, these documents have not been extensively used to reconstruct hurricane occurrence. In fact, most of the reference works (Poey 1862; Millás 1968; Fernández-Partagás and Díaz 1996) were developed using documents kept in the various American archives, without exploiting Spanish sources.

The Spanish government of the American territories was highly bureaucratic, producing an extraordinary number of documents. In fact, the main Spanish depository, the Archivo General de Indias, General Archive of the Indies (AGI), keeps more than 8 linear km of shelves with these documents. Over the past years we have started to recover hurricane information from different Spanish archives, including the AGI, Archivo del Museo Naval (AMN, Archive of the Naval Museum) and the Archivo General de la Armada (AGA, General Navy Archive). To date, the results of this search have allowed us to identify 70 previously unreported hurricanes and produce a database freely available on the web (www.ucm.es/info/tropical), which can help to refine our long-term view of hurricane behaviour (García-Herrera et al. 2004, 2005a). The information in these documents dates the occurrence of individual hurricanes and also provides information on their impacts and the prevailing meteorological conditions during the hurricane season.

The aim of this paper is to show how documents kept in Spanish archives are relevant for the search for hurricane evidence, problems involved in gathering this evidence, and the types of additional information they contain.

\section{Material and methods}

This paper draws on the results of two years of systematic studies in the AGI, the documents of which contain evidence of hurricanes and their impacts. Details on the organization and content of the AGI have been described in García et al. (2001). In summary, the AGI is administered in 16 sections, each of which contains a variable number of 'bundles', ranging between 48 and 18760 . We have examined 424 such bundles and found a variety of document types from different locations. Table 1 lists the sections that have been searched. The research team embraced expertise from two areas: two historians with previous experience in the searching and analysing documents in the AGI, and four climatologists/meteorologists. A pilot study produced an opportunity for greater mutual understanding between the two groups; the historians could understand what climatologists demanded and these, in turn, could better interpret the documents' contents. Additionally, it provided guidelines on the type of information to be searched and the documents and sections most likely to contain hurricane evidence. As a consequence, the search was mainly focused in the following sections: Gobierno (Government), Contratación (Contracts) and Papeles de Cuba or Cuba (Cuban Papers).

The Government section is by far the largest in the AGI. It covers the period 1492-1898 and contains 18760 bundles with information on the government of the Consejo de Indias (Council of the Indies). It is divided in two large groups; the documents from the Audiencias (Courts), which are organised geographically, and those in the subsection Indiferente General (General Miscellaneous), which contain documents that are not related to any specific territory. Each Audiencia corresponds also to an AGI subsection. For this paper the most relevant are Santo Domingo and Mexico. The first one has papers from Santo Domingo itself, Cuba, Puerto Rico, Jamaica, Florida and Louisiana, all dated between 1518 and 1852. The Mexico section 
Table 1 Distribution of the bundles examined according to the AGI sections/subsections

\begin{tabular}{llr}
\hline AGI section & Existing bundles & Examined bundles \\
\hline Gobierno (Goverment), Subsection Santo Domingo & 2720 & 132 \\
Gobierno (Goverment), Subsection México & 3196 & 100 \\
Gobierno (Goverment), Subsection Indiferente General & 3297 & 49 \\
$\quad$ (General Miscellaneous) & 6335 & 41 \\
Contratación (Contracts) & 2967 & 38 \\
Papeles de Cuba (Cuban Papers) & 8000 & 64 \\
Others: Patronato (Patronage), Justicia (Justice), Correos & & \\
$\quad$ (Mail), Escribanía (Notary), Governement subsections of & & \\
$\quad$ Guatemala, Santa Fe and Panama & & \\
\hline
\end{tabular}

contains information on Mexico and Central America for the period 1519-1856, and here is to be found most of the correspondence of the colonial authorities in the form of letters and documents from Viceroys, Royal officers and individuals. These papers contain information on claims and compensations after natural disasters and incidents that had an affect on maritime trade.

The Contracts section is the second largest in the AGI and contains documents from the Casa de Contratación (House of Trade) for the period 1492-1794. In this section, the emphasis was placed on the documentation relating to trade between the Americas and mainland Spain, particularly from the fleets that sailed annually between them as well as the reports from admirals and fleet commanders.

The section Cuban Papers contains the volumes from the Capitanía General de Cuba (Captain General of Cuba) for the period 1712-1872. They consist mostly of papers form the Governors and include documents from Cuba, Louisiana and Florida and they complement the coverage provided by Contracts section. In this section, the official correspondence between governors and the captains general was selected for study, as it should contain most of the information on the impacts of natural hazards.

Following the pilot study the work was organised as follows: the historians searched documents in the AGI and produced literal transcriptions of those items that potentially contained evidence of hurricanes. These transcriptions were added to a working database. Two meteorologists then independently examined the transcriptions and decided if the report included information on a hurricane, a storm, or any other type of phenomena. When discrepancies occurred, a joint analysis was made including a third member of the team. After this, all the reports containing information on hurricanes and storms were included in the final database. The content of the database and the criteria used the analysis of the transcriptions can be found in García-Herrera et al. (2005a). As a result of these eyewitness accounts, we identified 134 hurricanes, 70 of which were previously unreported.

\section{Hurricane evidence}

In order to show the complexity of the search made in the AGI and the diversity of the documentary material that was used we present the following case studies:

1. The hurricane that occurred on November 6th 1605, in the Caribbean Sea (Bajos de las Víboras and Serrana-Serranilla).

2. The hurricane that occurred on November 1, 1774 in Havana. 


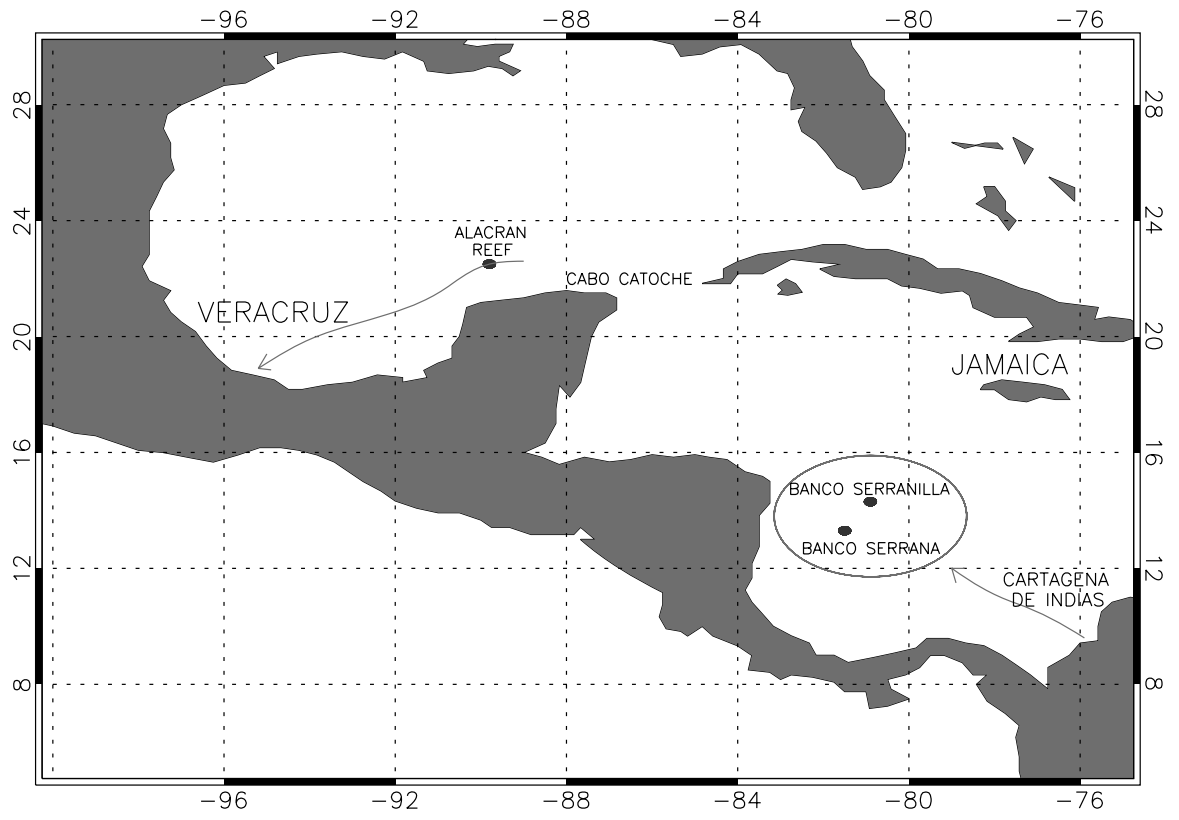

Fig. 1 Location of the storms reported in cases 1 and 3

3. The hurricane that struck the Spanish fleet in the Caribbean Sea on September 20, 1600

4. The hurricanes that occurred in Louisiana on 10 and 31 August 1794.

5. The hurricane that struck Havana on August 27-28, 1794.

Cases 1 and 2 are reported in numerous documents kept in different sections of the AGI. They illustrate the difficulty of identifying all the evidence for a hurricane when it is spread across a range of sources. Case 3 provides an account of the occurrence of a hurricane embedded within an episode of a polar outbreak, a not infrequent meteorological event in the area. Cases 3 and 4 identify two entirely new storms. Case 5 is one of the earliest descriptions of a hurricane that includes twice-hourly instrumental observations. In all cases, we present the documentary evidence and discuss them alongside other chronologies.

\subsection{Case 1: November 6th 1600, Vívoras-Serranilla}

On November the 6th 1605, at the shallows of Las Viboras, a storm surprised General Luis de Córdoba's Armada and Fleet arriving from Tierra Firme. ${ }^{1}$ on a journey from Cartagena de Indias to Havana. The fleet had left Cartagena on November 1st 1605 and traveled without problems until the night of November the 6th when, at fifteen and a half degrees of latitude, between the shallows of la Serrana and la Serranilla, a hundred leagues ${ }^{2}$ from the port of Cartagena, the fleet was struck by the storm. Figure 1 shows the Víboras-Serranilla area. Table 2 presents the transcriptions of all the documents that we have identified as containing reports on this event.

\footnotetext{
${ }^{1}$ Tierra Firme was the name given to present day Colombia and Venezuela.

2 The league was defined as the distance that a man or a horse could walk in an hour. The marine league was aproximately equal to $5.55 \mathrm{~km}$.
} 


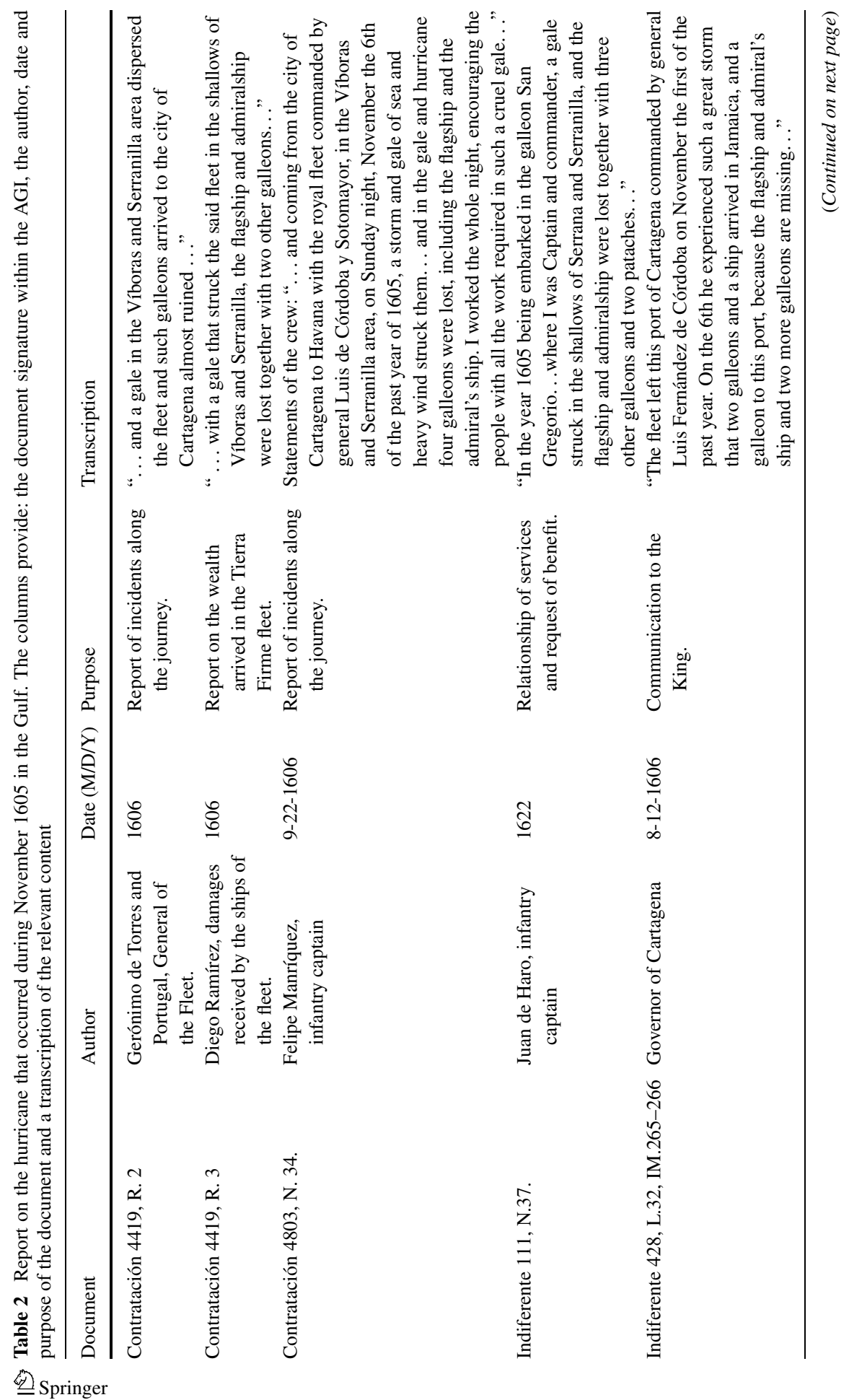




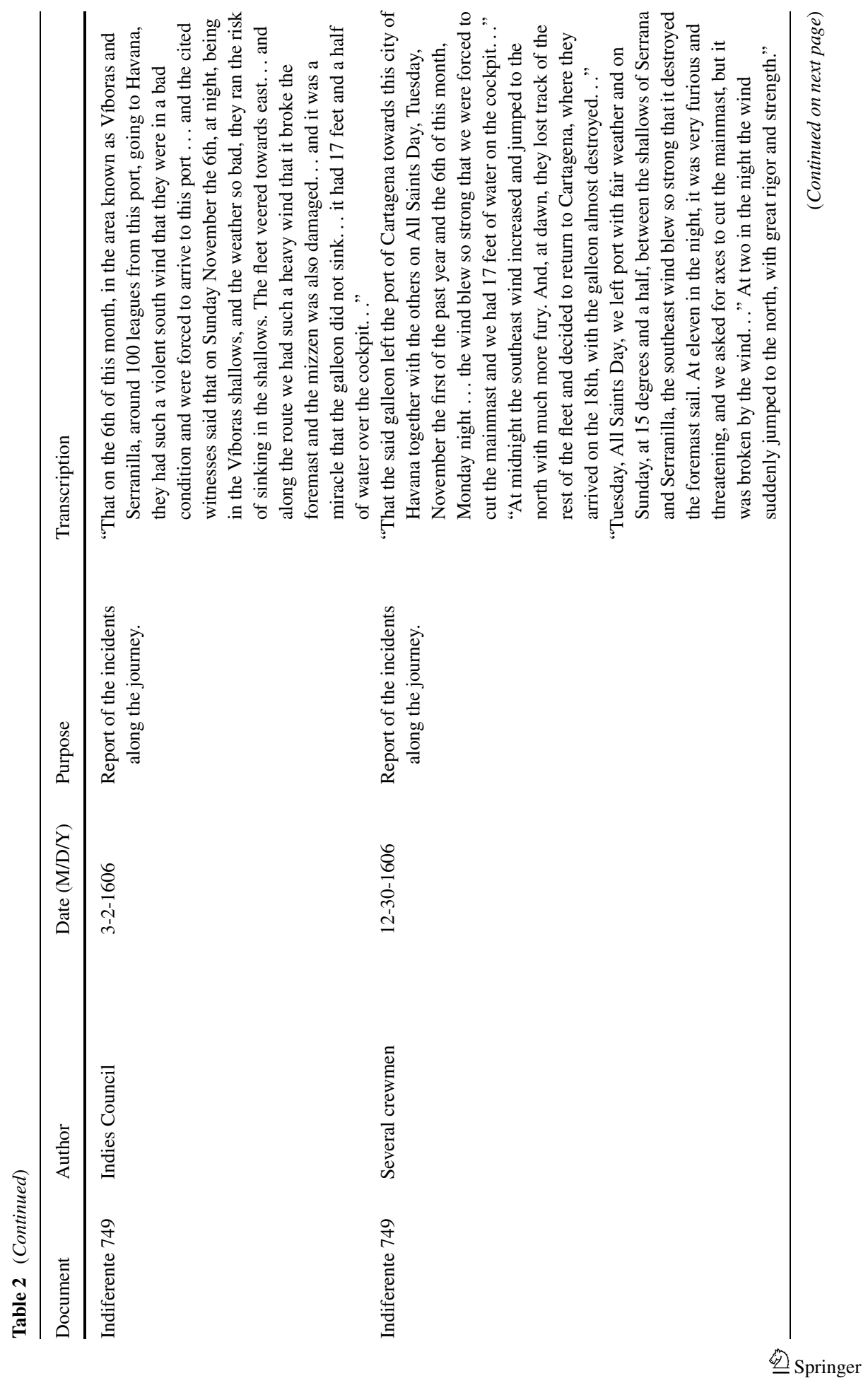




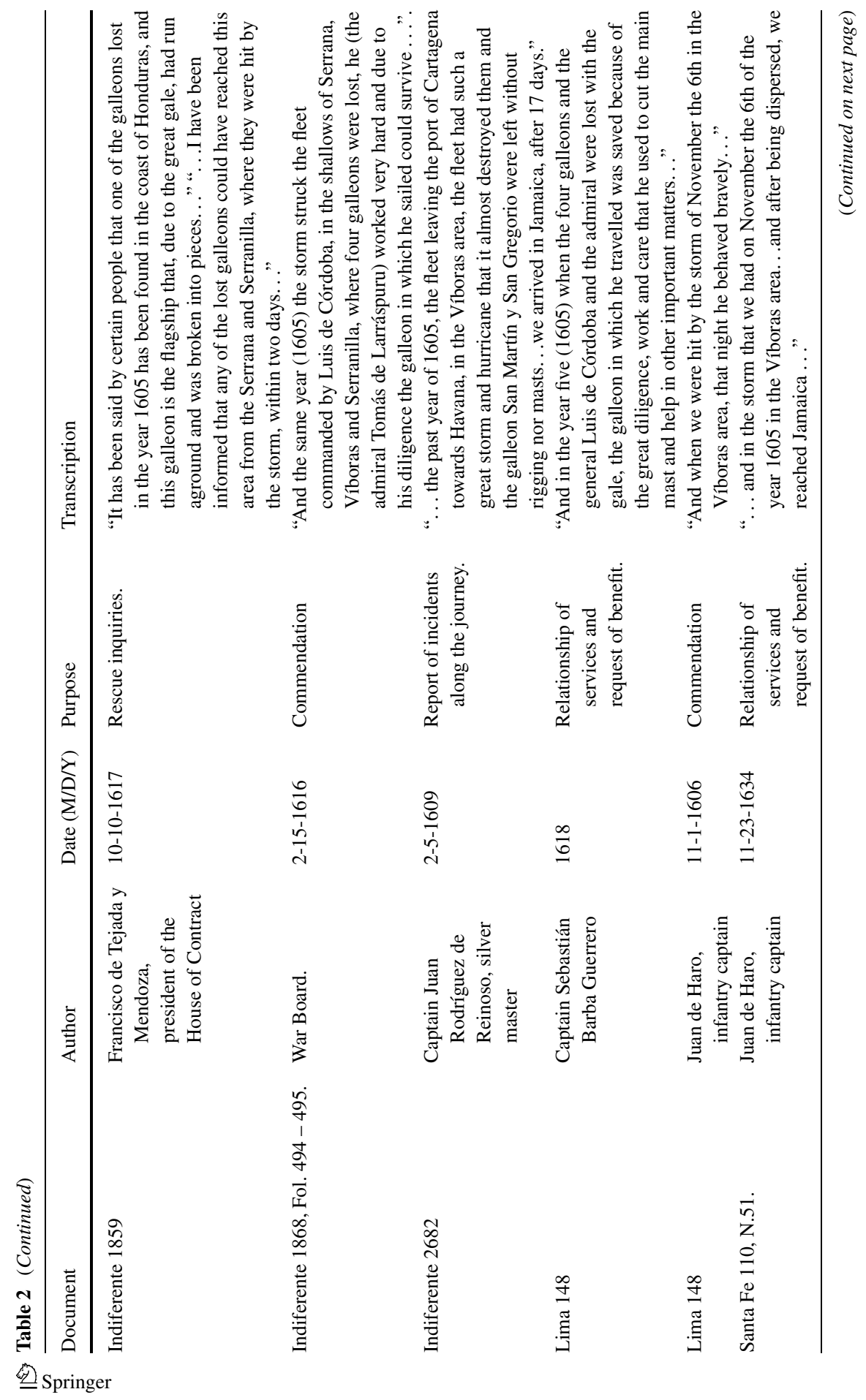




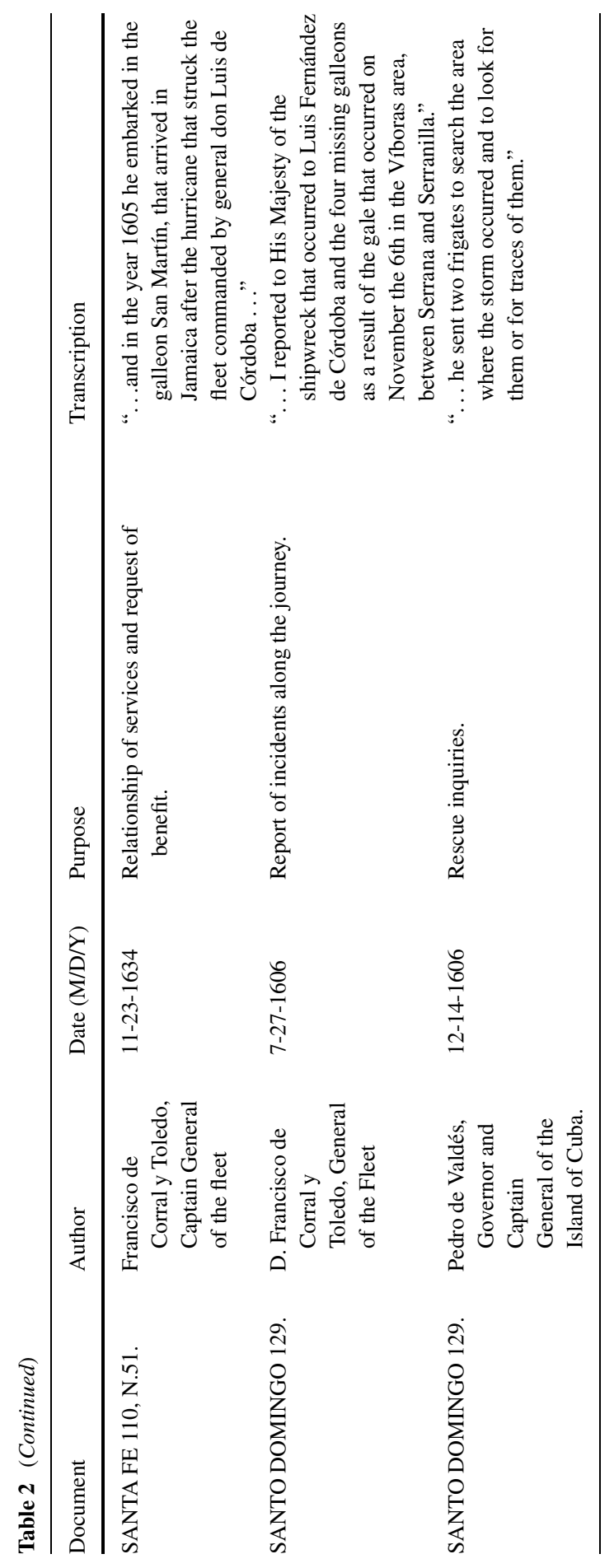


Its effects are reflected in the abundant documentation that circulated between the colonial authorities and Spain. Sixteen documents have been located in various sections and subsections of the AGI, which is an indication of the magnitude of this storm. These letters, mostly sent to the Council of Indies as the main office in charge of the administration of the American territories and the Casa de Contratación (House of Trade), which was responsible for commerce and travel to the colonies, include: reports from witnesses present during the storm, such as captains, pilots, masters and the crew of the galleons that experienced the hurricane; descriptions of the voyage made by the authorities shortly after the ships docked in port, and requests in recognition of distinction and service made some years later with the object of receiving some sort of Royal benefit.

These documents allow us to infer the intensity of the storm, especially useful are those of the declarations of the ships' crews, for example A.G.I. Indiferente $749:^{3}$

'the southeast wind blew so strong that it destroyed the foremast sail. At eleven in the night, it was very furious and rigorous, and we asked for axes to cut the mainmast, but it was broken by the wind (...). At two in the night the wind suddenly jumped to the north, with such a rigor and strength that it also broke the foremast'

The storm's intensity can be gauged to be a hurricane by the sinking of four galleons, including the flagship and the Admiral's ship and two other boats. The remains of the sunken vessels could be found on the coast of Honduras for a long time. The rest of the ships had their sails torn and masts broken. All were close to being shipwrecked and without leadership and tried to change the route of their voyage towards a closer port. Some of the ships separated from the main fleet and managed to reach the coasts of Jamaica and Cartagena of the Indies, attributing their survival to divine intervention.

It is interesting to note that the collection of this information required searches in five sections/subsections, namely Santo Domingo, corresponding to the main islands, Santa Fe to Tierra Firme, Lima, General Miscellaneous and Contracts. To date no other hurricane that we have identified in the Spanish archives is reported in so many units of the AGI.

\section{Discussion}

This hurricane is included by Millás in his chronology (Millás 1968) as case 4, '1605 Serranilla Bank, Western Caribbean Sea', but he could not identify its date of occurrence. The information that we recovered allowed us to date the hurricane with precision and supplied also a very detailed description of its impact. We suggest the main reason that we could better characterize this storm results from the fact that Millás used secondary sources only, while we employed primary information that provides a richer and more precise description of the hurricane.

\subsection{Case 2: November 1st 1774 Havana, Cuba}

Twenty-five documents related to the occurrence of this hurricane have been located among the bundles of the Government Section of the AGI (Audiencia de Santo Domingo and Papeles de $C u b a$ ). Their content and characteristics are described in Table 3. Most accounts come from captains of different partidos (counties), each of whom produced reports on the damage

\footnotetext{
${ }^{3}$ References to manuscript sources in the Archivo General de Indias are denoted by the initials AGI, followed by the name of the section of the Archive where the manuscript is located, and a number identifying the legajo, or bundle, to which the manuscript belongs.
} 


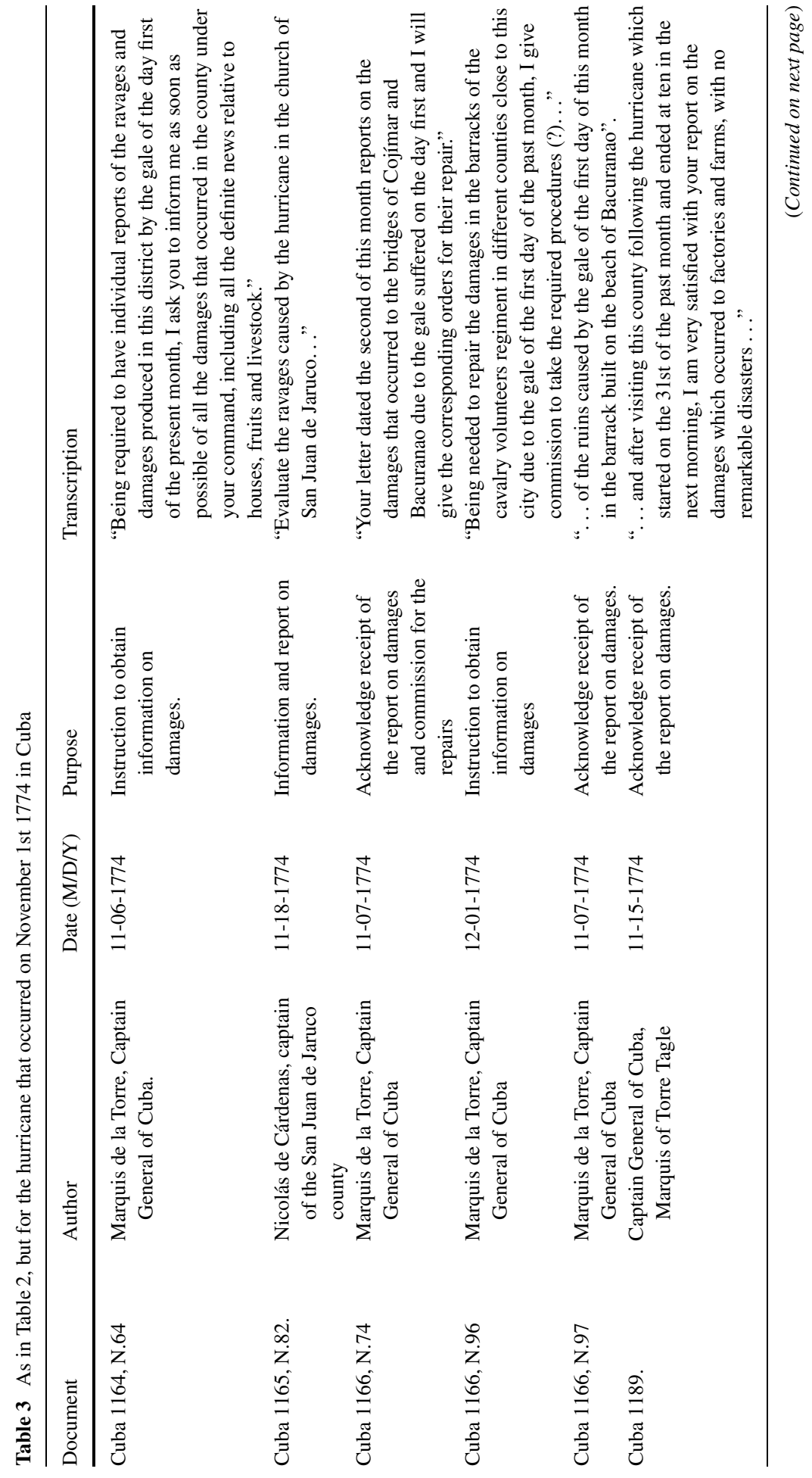




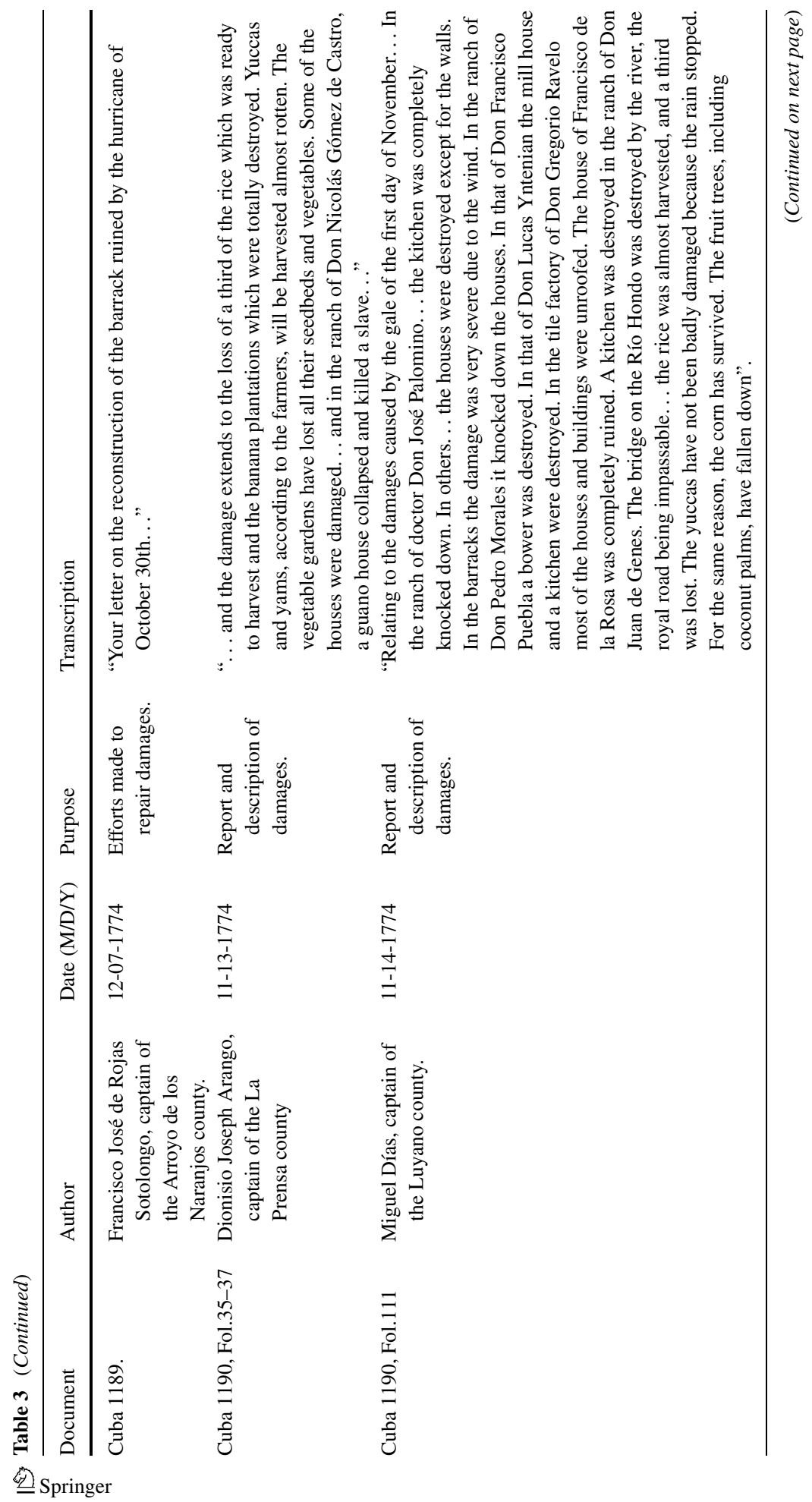




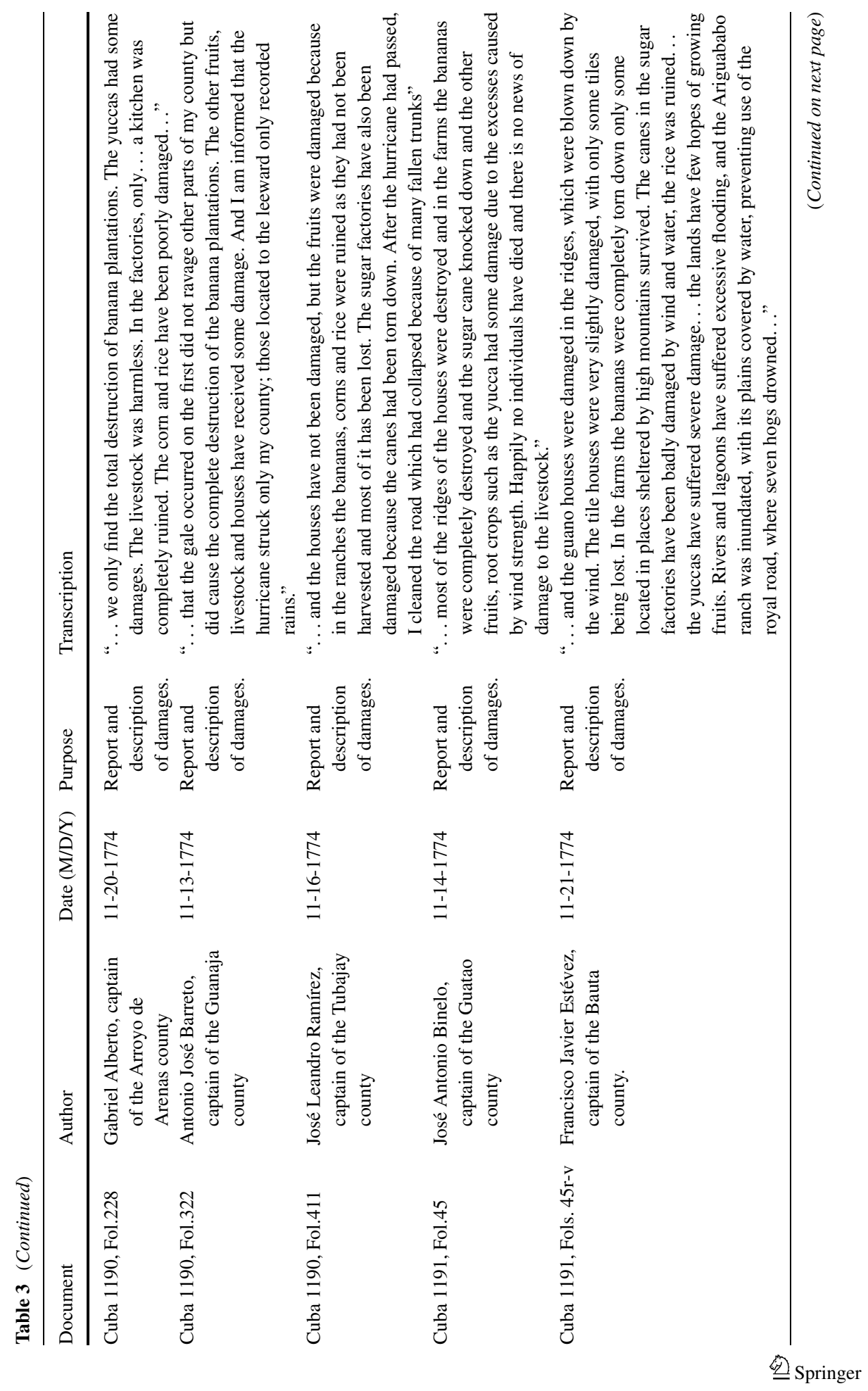




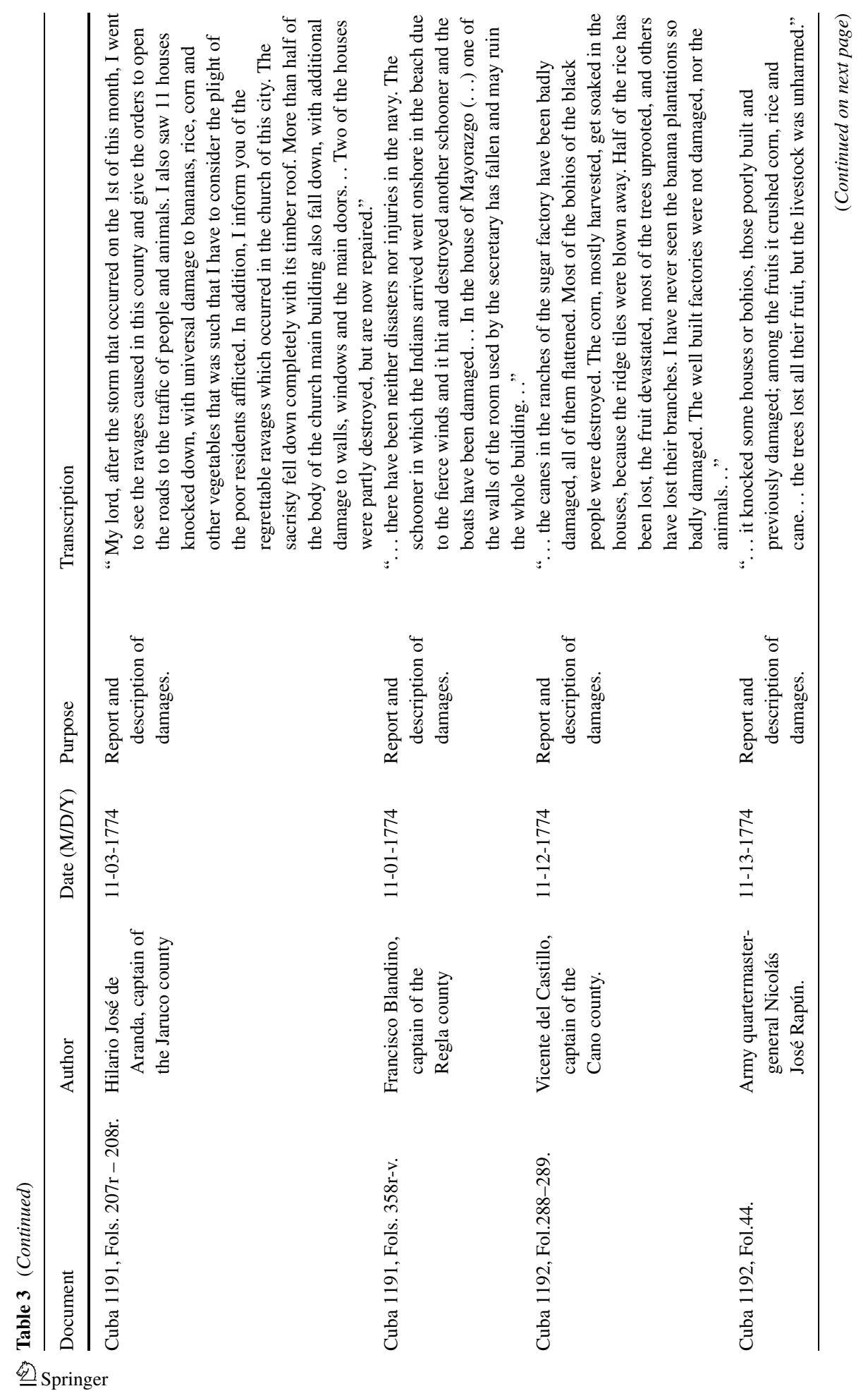




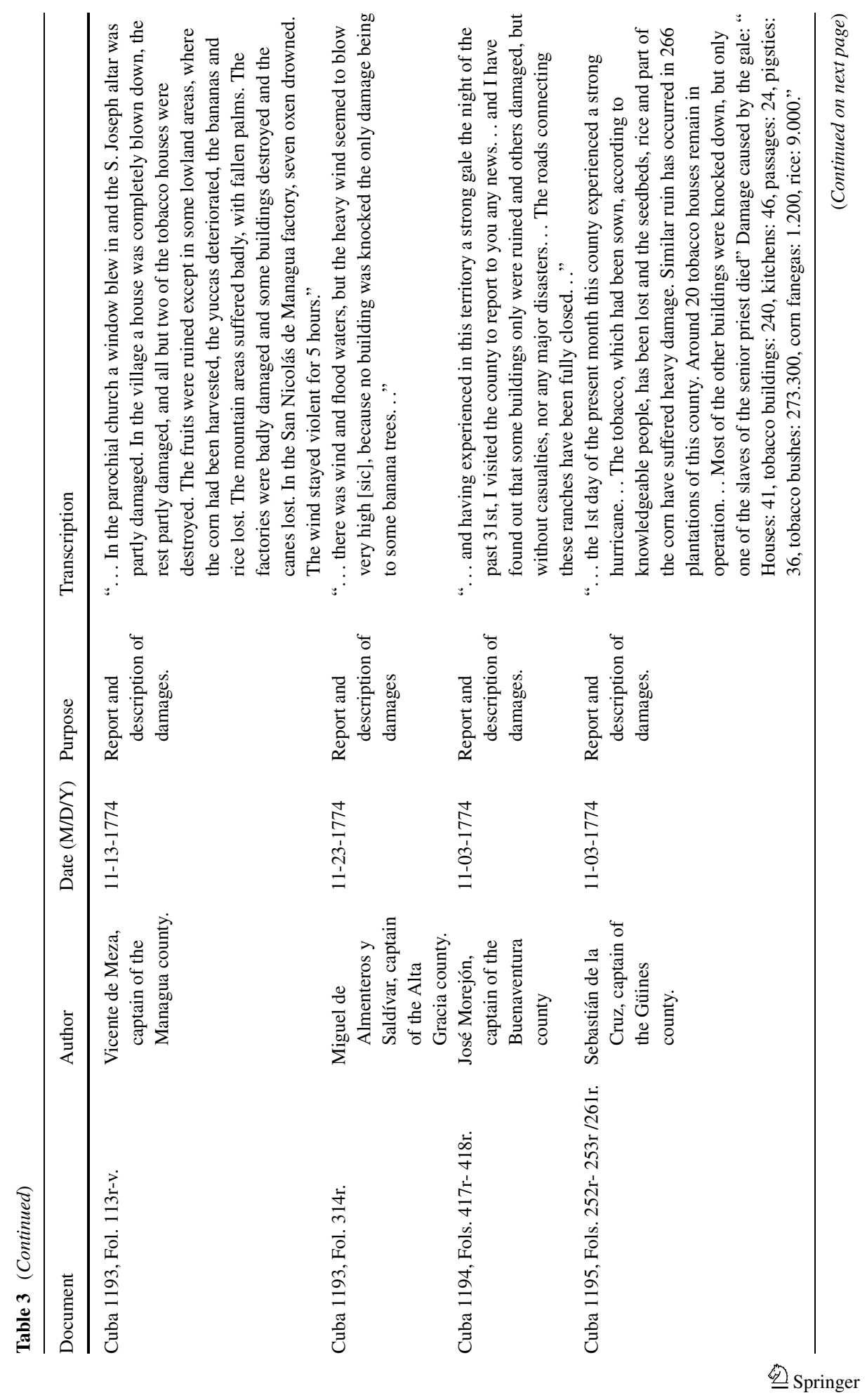




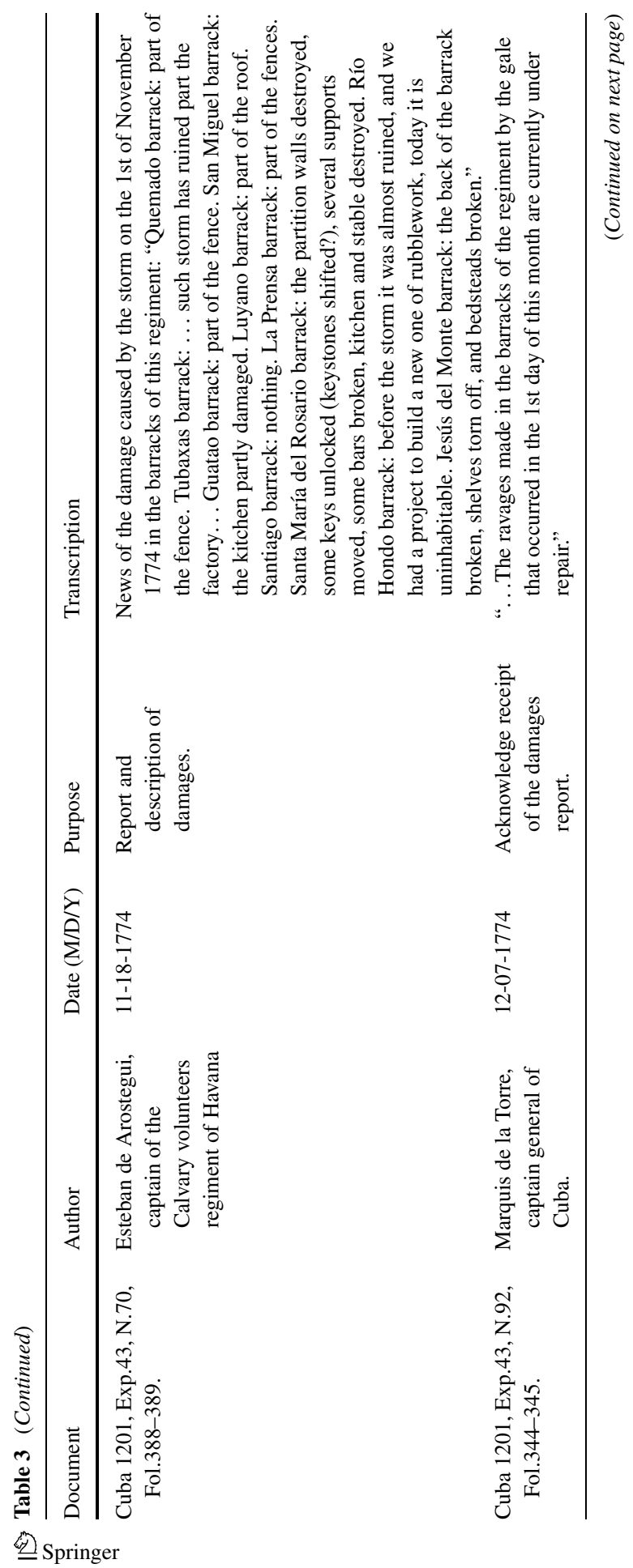




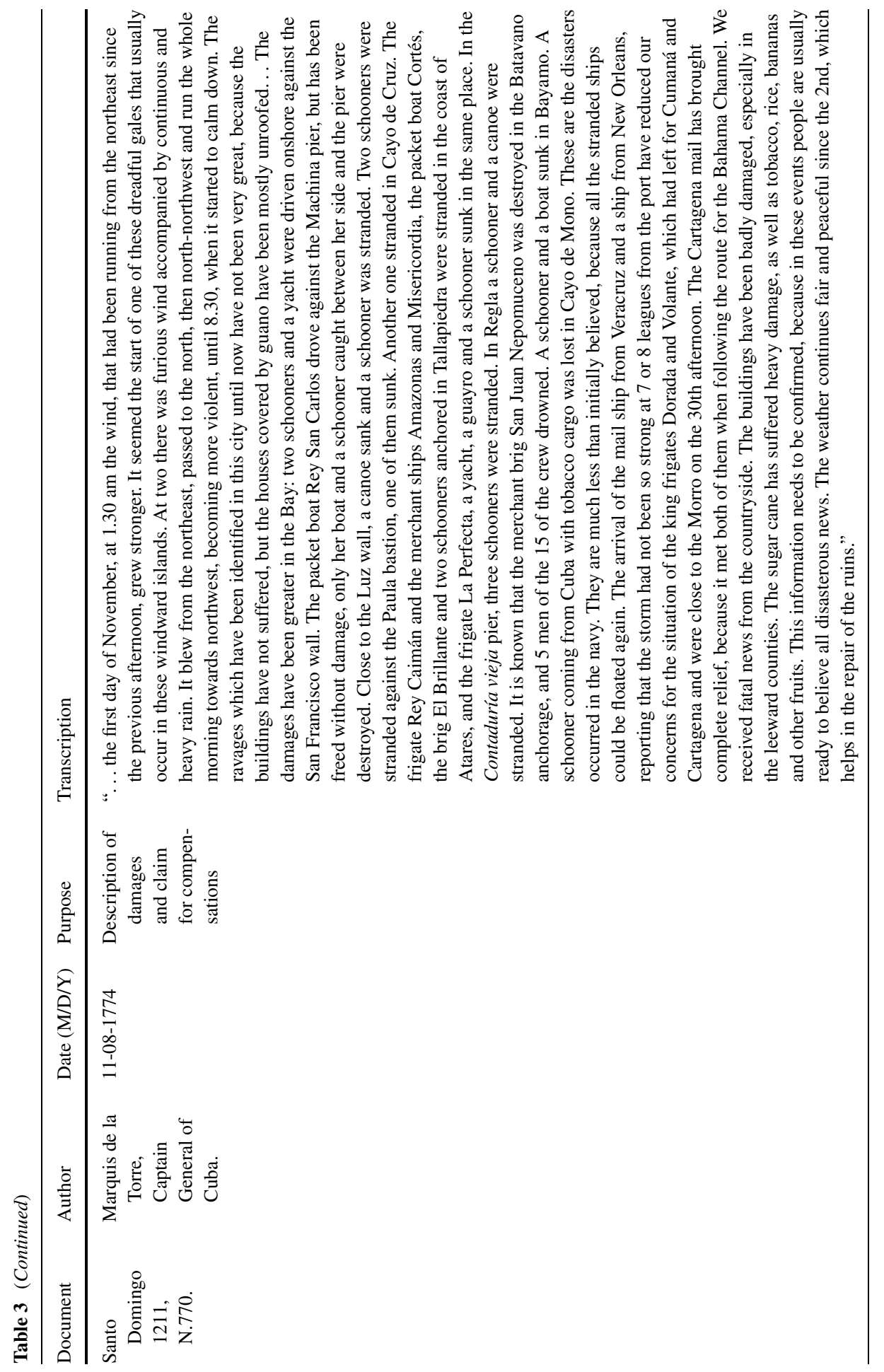




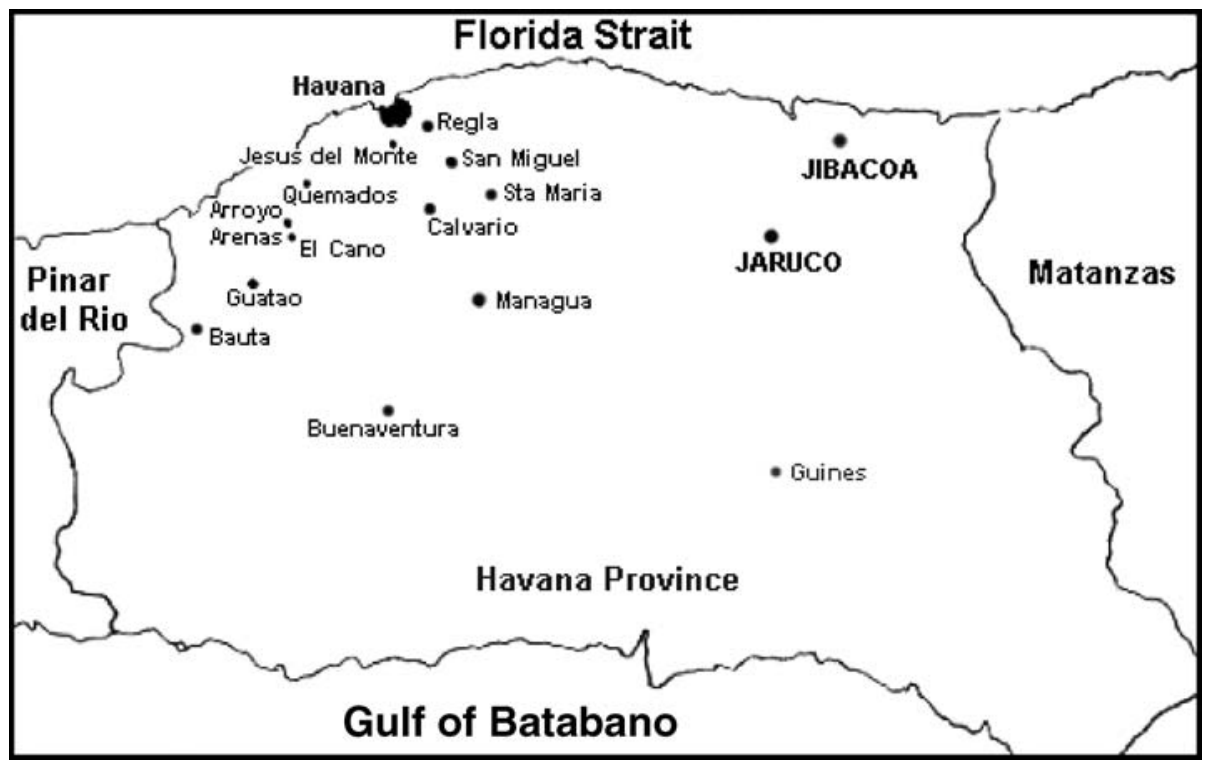

Fig. 2 Counties affected by the hurricane of November 1st, 1774

in their districts and following orders from the Marquis de la Torre, Captain General of Cuba, who needed to report to the Indies Council to receive economic help for the reconstruction of the island. Consequently, this case mostly has information on the impacts on farming and on damage to military installations, roads and bridges.

The documents allow us to reconstruct the chronological sequence of the passing of the hurricane through the city of Havana using the witnesses' testimonies, such as:

'the first day of November, at 1.30 am the wind, that had been running from the northeast since the previous afternoon, grew stronger. It seemed the start of one of these horrible gales that usually occur in these windward islands. At two it was furious wind accompanied by continuous and heavy rain. It blew from the northeast, passed to the north, then north-northwest and run the whole morning towards northwest, getting more and more violent, until 8.30, when it started to calm down.'

By November the 2nd the weather had become fair and pleasant (AGI Santo Domingo 1211, N.770). The other reports, made by independent authors, show two main facts:

- The storm affected only the western part of Cuba, described as the windward side in most of the reports. Districts considered to be on the leeward side (Alta Gracia and Guanaja) seem to have suffered only minor damage, mostly in the banana plantations, and the damage was mainly from rain and not wind. Figure 2 shows the location of the affected counties.

- Even when abundant damages are reported, they are not considered to be very heavy by the reporting individuals. The impacts are mostly focused on farming, especially in the banana plantations, and in the poor buildings (guano houses). Only two casualties are reported, both of them due to fallen buildings (AGI Cuba 1190 and Cuba 1195). Livestock seem to have been unharmed and no claims of severe or irrecoverable damage are found. Thus, we can assume that it was a low intensity hurricane when striking Cuba. 


\section{Discussion}

For the year 1774, Millas (1968) reports a hurricane in Cuba, but he is not able to date it, or to identify the affected area. Millás bases his assessment in Fernández de Castro's (1871) book on the hurricanes that occurred in Cuba. In this book there is a reference to a report of the Marquis de la Torre on the strong hurricanes suffered in the years of 72 and 74, but no more information is reported. In a recent revision of Poey's chronology, Chenoweth (2006) identifies this hurricane as number 121, (see his Table 4), affecting Cuba to north of Bahamas to $30 \mathrm{~N} 67 \mathrm{~W}$. This assessment is based (Chenoweth personal communication) on a variety of logbooks, newspaper items and the Thistlewood record of Jamaica (Chenoweth 2003). In fact, the records contained in Table 3 are the only ones available for land areas of Cuba, since only a newspaper account of a ship that encountered the hurricane at sea between Havana and Matanzas was previously available.

In this case the AGI documents allow us for the first time to identify the land area affected by this hurricane and to make an initial assessment of its intensity.

\subsection{Case 3: September 1600}

During the month of September, the Mexican coast of the Gulf of Mexico, between Cabo Catoche and Veracruz, registered various windstorms that disrupted the arrival of the ships of the New Spain fleet, sailing from Spain to Veracruz. Throughout the month of September of 1600, a number of significant weather phenomena occurred on the coast of Veracruz and the Channel of the Bahamas. We have identified eight documents from the AGI, containing information, related to these incidents (they are summarized in Table 4). Most were written by personnel of the fleet from General Pedro de Escobar Melgarejo to clerks, and they include direct testimonies from masters, sailors and pilots.

On the 4th of September, General Pedro de Escobar Melgarejo, on board the Flagship of the Spanish fleet, wrote from the Sonda de los Alacranes (Alacran reef, see Fig. 1) announcing that he had remained with his fleet awaiting an auspicious time to arrive at port. On the 12th a strong west by northwest wind surprised the fleet, and boats were obliged by the fierce weather to separate from formation. The next day, a strong north wind blew and continued until the 17th. On this day, winds changed and a great west-by-southwest wind began twenty leagues from Veracruz, which quickly became a violent hurricane. On the morning of the 18th witnesses refer to having survived a terrifying storm, "never thought nor imagined before" that was caused by the hurricane's north wind. On the 21 st of the same month another very strong storm from the north and continued until the following evening. The 26th of September the north wind began again, blowing over La Cabeza, a shoal two leagues from the port of San Juan de Ulúa. ${ }^{4}$ This wind, which lasted the entire following day, greatly complicated the entry of the ships into port. Witnesses say that it lasted until the first days of October. Because of these storms and hurricanes, only twenty-nine of the forty-three ships that composed the fleet of General Melgarejo, reached the port of San Juan de Ulúa. Two of them arrived at Campeche, forced by the winds, ten were beached on the coast and two sank. The human and material losses were considerable. Due to the violent weather the crews had to throw much of the cargo overboard, leaving half the holdings in the sea. The lists of the dead are not precise, but we know that from the ship the Catalina, which "the sea swallowed," that only the master and two or three seaman were saved.

\footnotetext{
${ }^{4}$ San Juan de Ulúa was the port of Veracruz.
} 


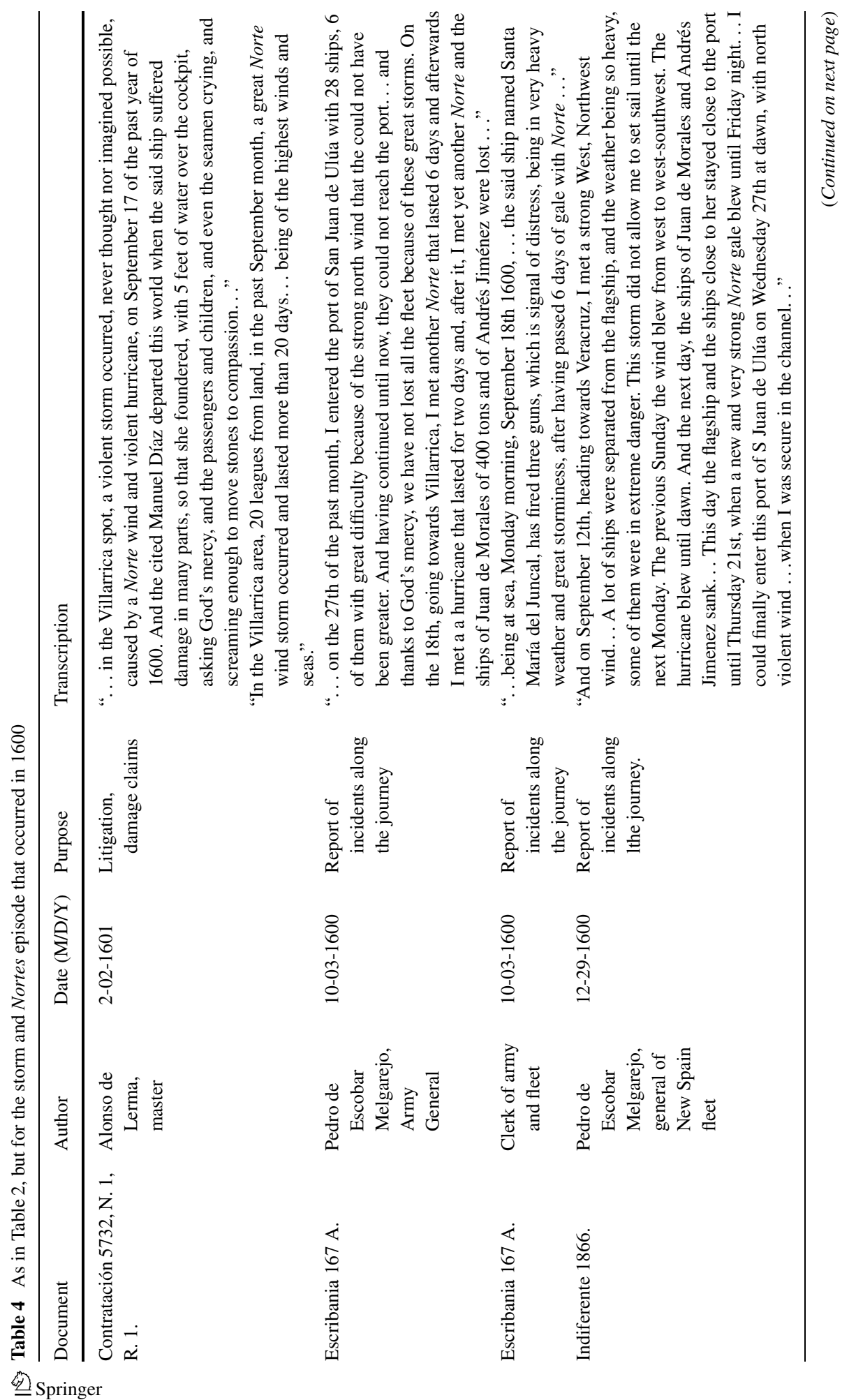




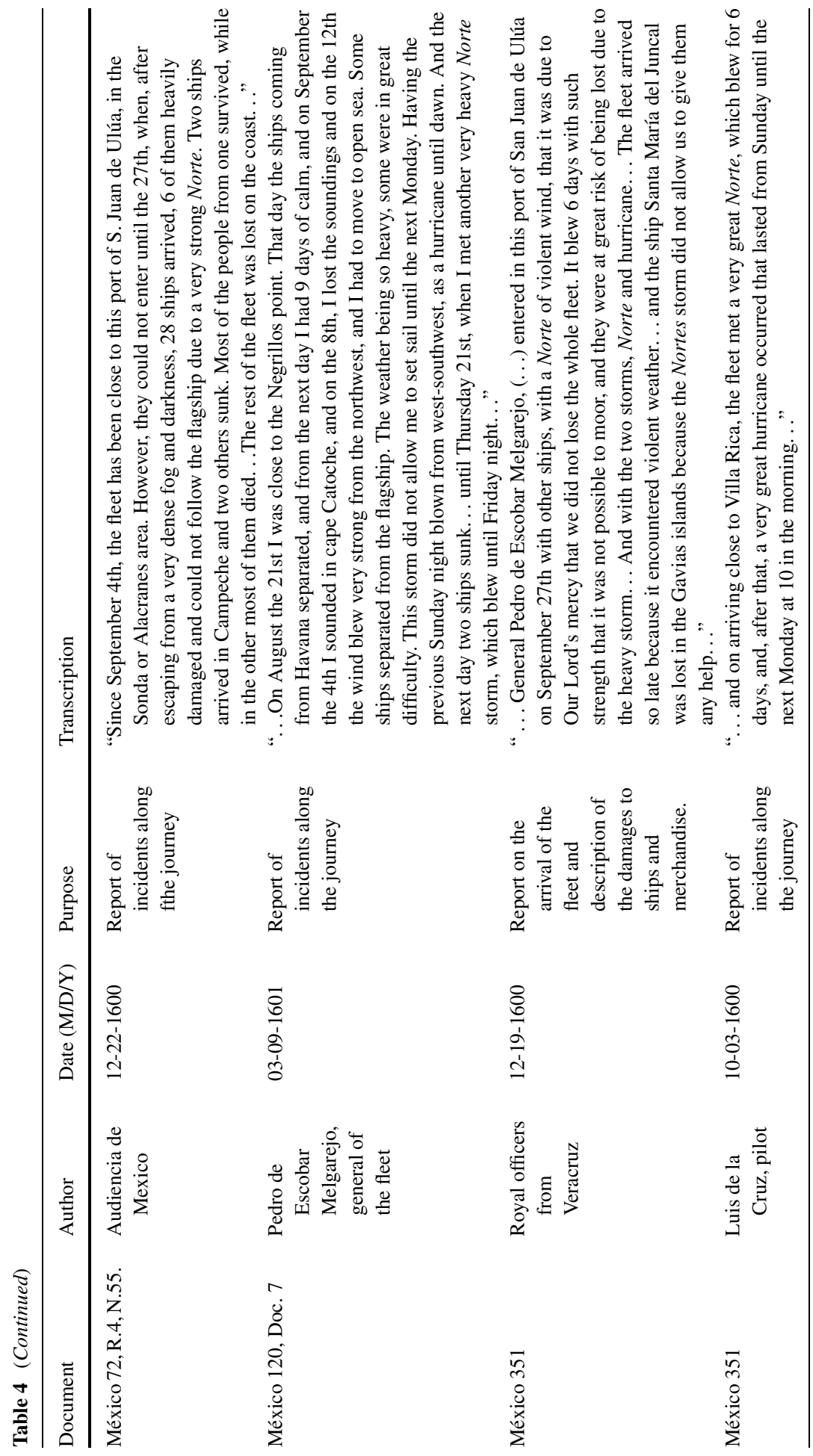




\section{Discussion}

During northern winter, cold air surges of polar origin may penetrate deep into the Gulf of Mexico and Caribbean region. They are caused by a build-up of cold air in the higher latitudes of the North American continent and a concomitant steepening of meridional pressure gradients. These sudden outbreaks of cold air penetrating deep into Mesoamerica are accompanied by very strong winds that may blow at gale force for several days. They are known regionally as Nortes. Modification of the cold continental air over the relatively warm waters of the region often brings abundant cloudiness and rainfall to the windward sides of the region. These polar outbreaks sometimes lead to frost occurring in low-lying areas, with damage to crops, such as coffee, being not an uncommon occurrence.

The Spanish were well aware of this phenomenon since the early times of the conquest. The relevance to navigation within the Gulf of Mexico, specially the organization of the fleets which sailed annually between the colonies with the Spanish mainland, required that meteorological conditions were carefully scrutinized from the very early times of the conquest, particularly the wind and storm conditions.

A.G.I. Indiferente 2661 provides a description of the level of understanding around 1575 for Santo Domingo (Dominican Republic):

"The winds running in this Hispaniola Island are the east winds all the year, except in August and September, which is the season of hurricanes, which are big storms... The Nortes winds blow in November, December, January and February. They are very strong in this island and in New Spain (Mexico) and Honduras, and to shelter from them we have very good and safe ports".

The transition between the hurricanes season (July to November) to the start of the Nortes in November was a limit to navigation and it motivated abundant documentation on the best departure date, or on the problems for unloading the ships in Veracruz because of such outbreaks. Some examples can be found in: A.G.I. Mexico 2984, Letter of the Marquis Casa Tilly to Julián de Arriaga, Indies Secretary: Cádiz, October 7th de 1768, A.G.I. México 2489.

In this case the documents indicate that there were several Nortes spells during the second half of September, namely 13th-17th, 21st-22nd and 26th to the first days of October. Embedded within them, a hurricane struck the fleet in the Gulf on the 17th, between the Alacran reef and Veracruz. This hurricane has not been found in any previous chronology. For this year and month, Millás (1968) reports a hurricane on the 26th-27th in the Seas north or northeast of Havana but this hurricane struck a different fleet that commanded by General Marcos de Aramburu, when returning to Spain from Havana. Two documents in the AGI report on this hurricane: Patronato 255, N.2, G.5, R.1 and Indiferente 746.

\subsection{Case 4: the hurricanes of August the 10th and the 31st of 1794 in Louisiana}

On August the 10th of 1794 a hurricane devastated the territory comprising Baton Rouge and La Baliza, the mouth of the Mississippi, at a distance of 60 leagues (Fig. 3). Testimonies regarding this hurricane are summarized in Table 5. They come mostly from the governor and mayor of Louisiana, who were very concerned about the heavy damages and asked for support from the king. The greatest damage was suffered by the inhabitants of the mouth Springer 


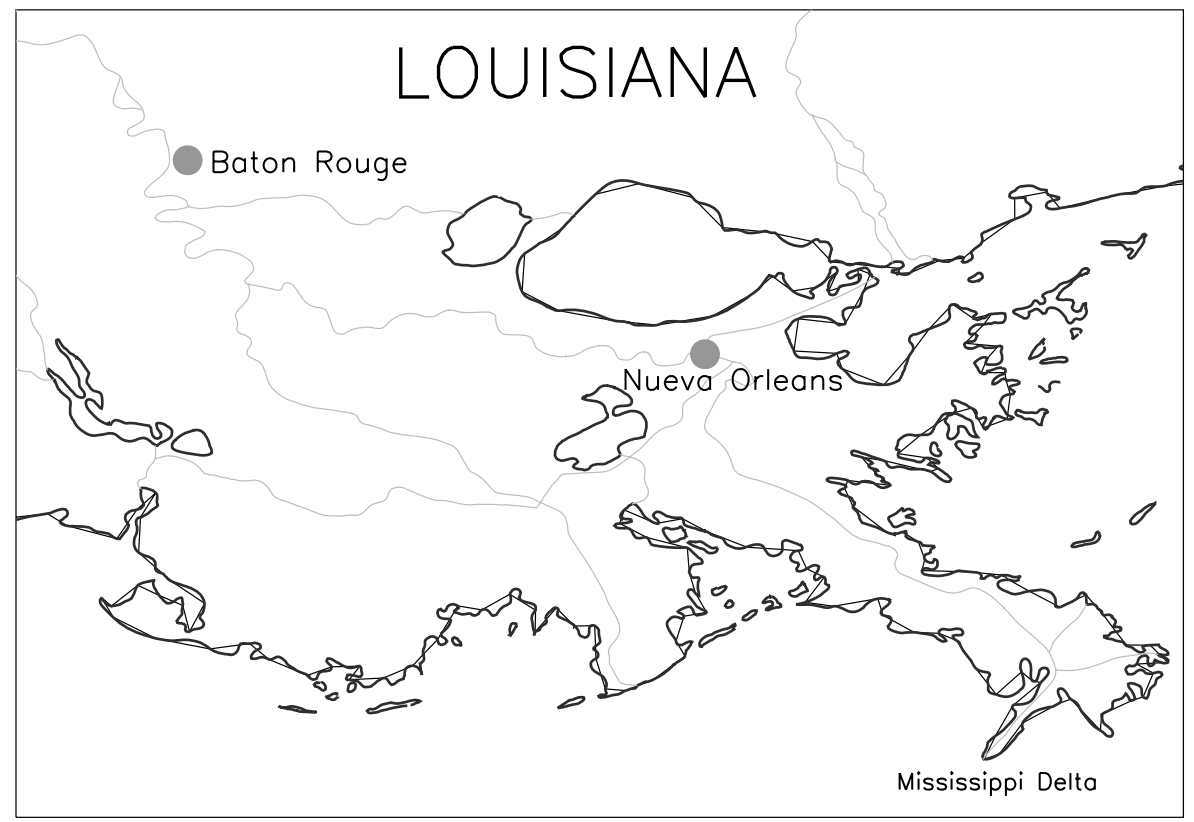

Fig. 3 Zone affected by the hurricanes of August the 10th and 31st of 1794

of the Mississippi and particularly those of the lower coast in an extension of nine leagues between New Orleans and Placaminas. ${ }^{5}$ These inhabitants

"scared due to the dreadful ravages caused by the sea waters, which reached more than six feet high, covering all the land and came with a terrible force to mix with the Mississippi waters, dragging trees, houses, livestock and everything that they found. So, everything is ruined to the last misery, the coast has been abandoned, and is now a desert extending eighteen leagues which previously were used to harvest rice."

In New Orleans the force of the hurricane began to be felt at ten o'clock at night. The storm maintained its intensity until seven o'clock the next morning, when it began to weaken. According to an attachment included in A.G.I. Cuba 1443 A, the ships in the port did not escape the fury of the hurricane, ten of them grounded on the beach and were heavily damaged, six were stripped of their masts, and all of the canoes, launches and smaller ships in the port were shipwrecked. They included two warships, three merchant frigates, two packet boats, four brigs and three schooners. The countryside suffered the ruin of almost all the rice, corn and indigo.

\section{Discussion}

The hurricane of the 10th has not been identified in any of the previously published chronologies (Chenoweth 2005) and the documents in the AGI are the only source of information available on this event.

\footnotetext{
${ }^{5}$ A.G.I. Cuba 479, N.33. Placaminas was a territory situated south of New Orleans, formed by a low and humid peninsula bathed by the Mississippi where this river meets the Gulf of Mexico. Its capital was Pointe a la Hache. Currently it is named Plaquemines.
} 


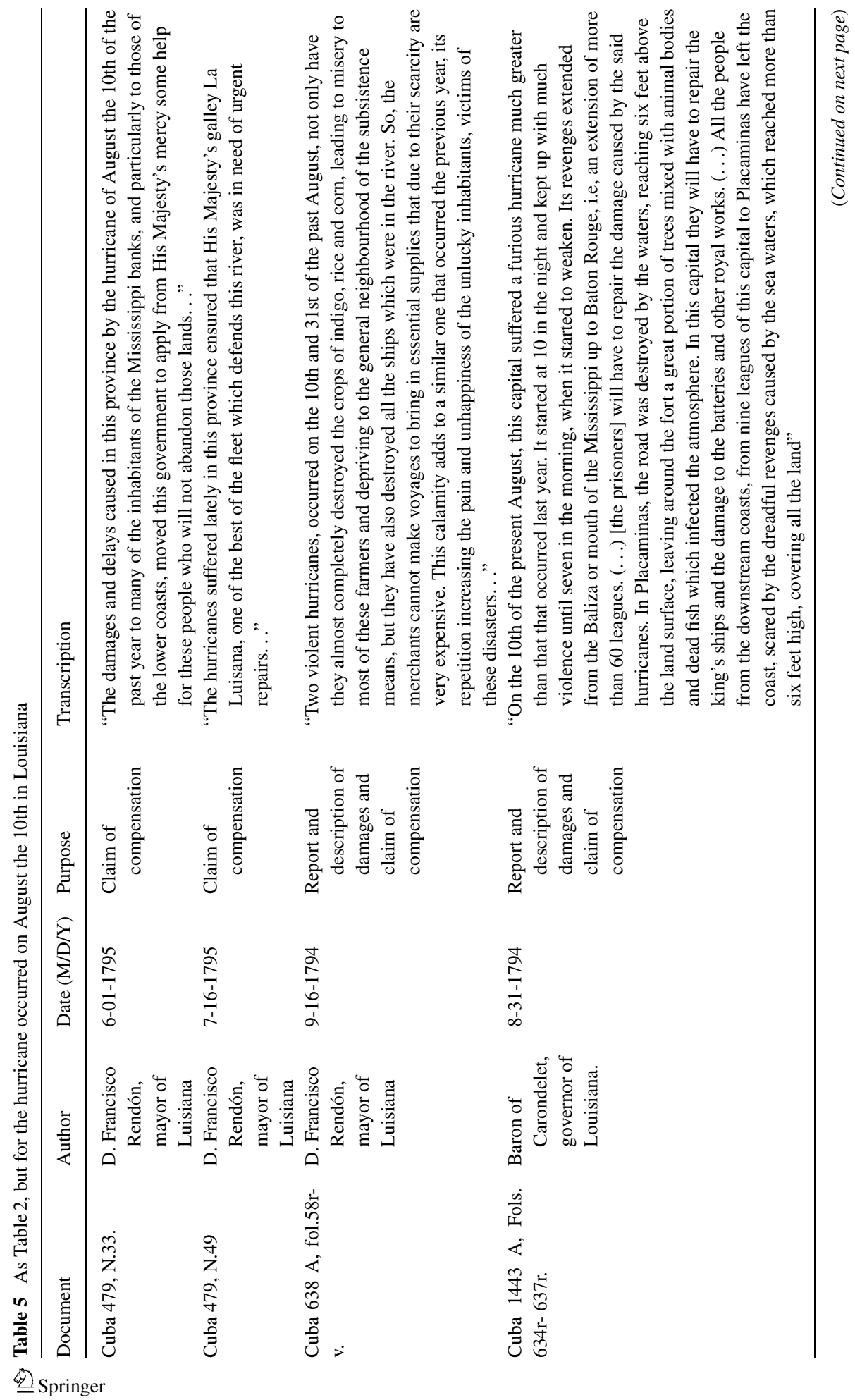




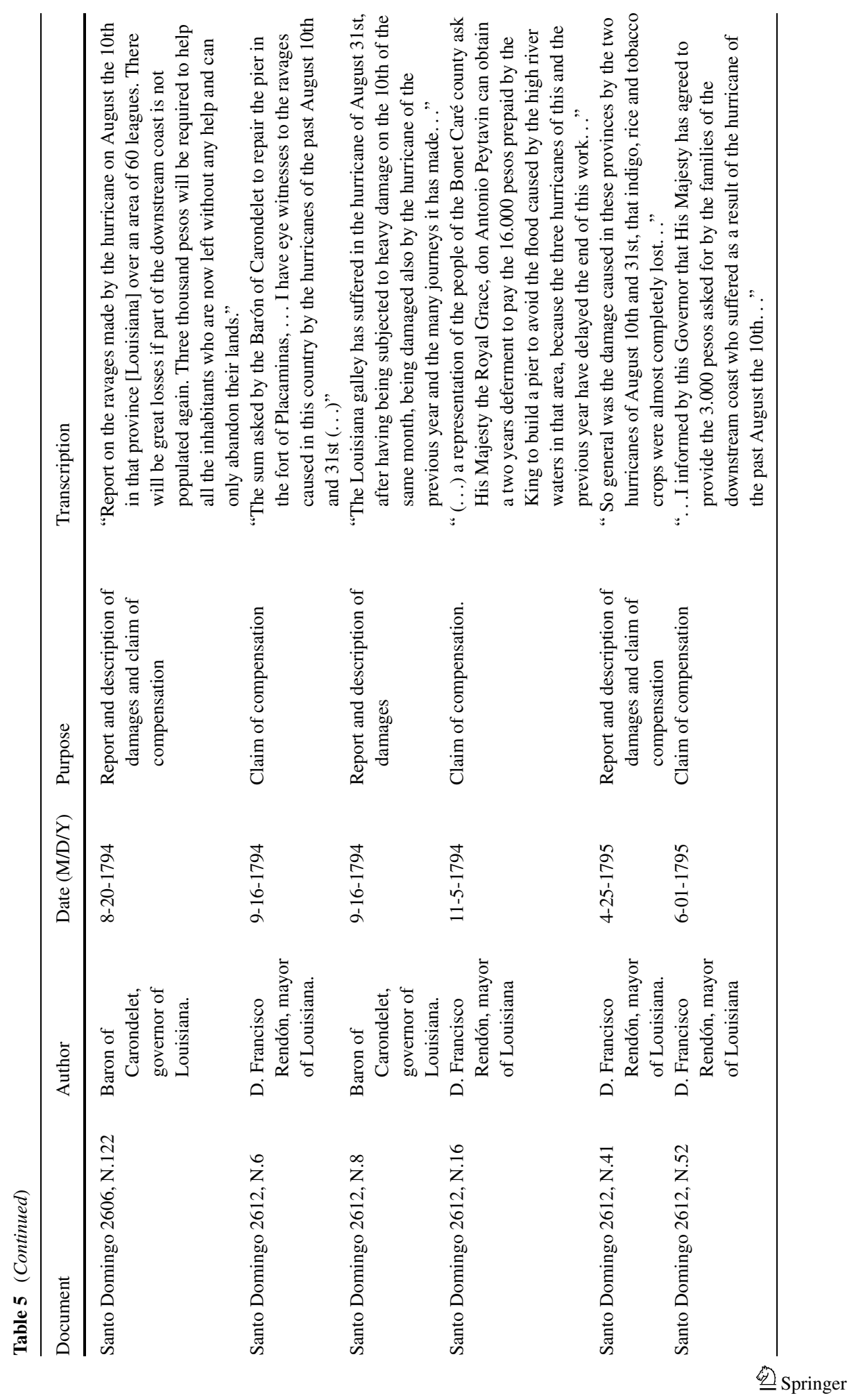


We do not find a description so detailed or exhaustive for the hurricane that occurred in this same region on the 31st of August. The testimonies recovered only mention the calamitous state of the region after the passage of both hurricanes (10th and 31st of August). The countryside and farms were totally destroyed, there were no ships to maintain commerce, and the inhabitants were in absolute despair. However, this second hurricane has been previously reported (see Chenoweth (2005), his storm 188, dated 25 August-1 Sept affecting Cuba to Louisiana) and should be connected with the next case that describes the consequences of this hurricane in Cuba

\subsection{Case 5: Hurricane of the 27th-28th of August 1794, Cuba}

On the 27th and 28th of August of 1794 a "fierce storm of water and wind" devastated the western part of the island of Cuba. The information found in the AGI (Indiferente 1559, N.152 and N. 155, and Santo Domingo 1254, N. 122) was sent to the metropolis by local authorities describing the damage to urban buildings, ranches and livestock in the rural areas, and to the ships docked in the ports. The intense rains associated with the storm caused rivers to rise and flood the fields. Table 6 shows the distribution of the damages in the different counties, while Fig. 4 shows the affected provinces.

\section{Discussion}

This storm is reported in Chenoweth (2005) as number 179, dated August 25 to September 1, 1794 and affecting the area between Cuba and Louisiana. The information available for this assessment comes mainly from newspaper accounts (Chenoweth personal communication). This storm attracted a lot of attention in the English-American press. One account mentions 64 ships driven ashore at Havana. The Boston Centinel has an account that is essentially the same as that provided by Millás (1968), who includes it as case 163. The Jamaica Royal Gazette mentions the storm in Louisiana on the 31st. According to Chenoweth, however, the newspaper sources can be misleadingly repetitive as they often drew on the same original accounts. Millás provides an incomplete set of observations made by the captain of the Spanish Navy, Tomás de Ugarte, and abstracted from the Havana newspaper Diario de la Marina.

This material is fully reproduced as Fig. 5. The observations have been transcribed without applying any corrections, since metadata are not available. Wind terms, on the other hand, have been translated according to the CLIWOC multilingual meteorological dictionary (García-Herrera et al. 2005b). Millás concludes that, if the minimum observed pressure of 29.5 inches is correct, the hurricane was rather weak. However, we have tried to reassess the intensity of the hurricane by applying the Saffir-Simpson (SS) hurricane scale and information about wind direction, surface pressure and damages. Although the SS scale evaluates the intensity based on the peak wind speed, it is possible to estimate the intensity from four different factors associated to the hurricane destructive power: maximum wind speed, minimum pressure, storm-surge and damage level. For this hurricane we have also wind direction and force. The wind was estimated at Beaufort 8 according to the CLIWOC dictionary during most of the 28th, its direction veering from NE, to $E$ and then to SE. As surface winds rotate counter-clockwise in a Northern Hemisphere tropical cyclone, this change in the wind direction reported in the Havana province suggests that the hurricane eye should have been to the south of Cuba and moving from East to West. As a result, the eye was moving from a position to the southeast of Havana (NE winds reported in this observatory) to a position to the south (E winds in the observatory) and finally to the southwest (SE winds 


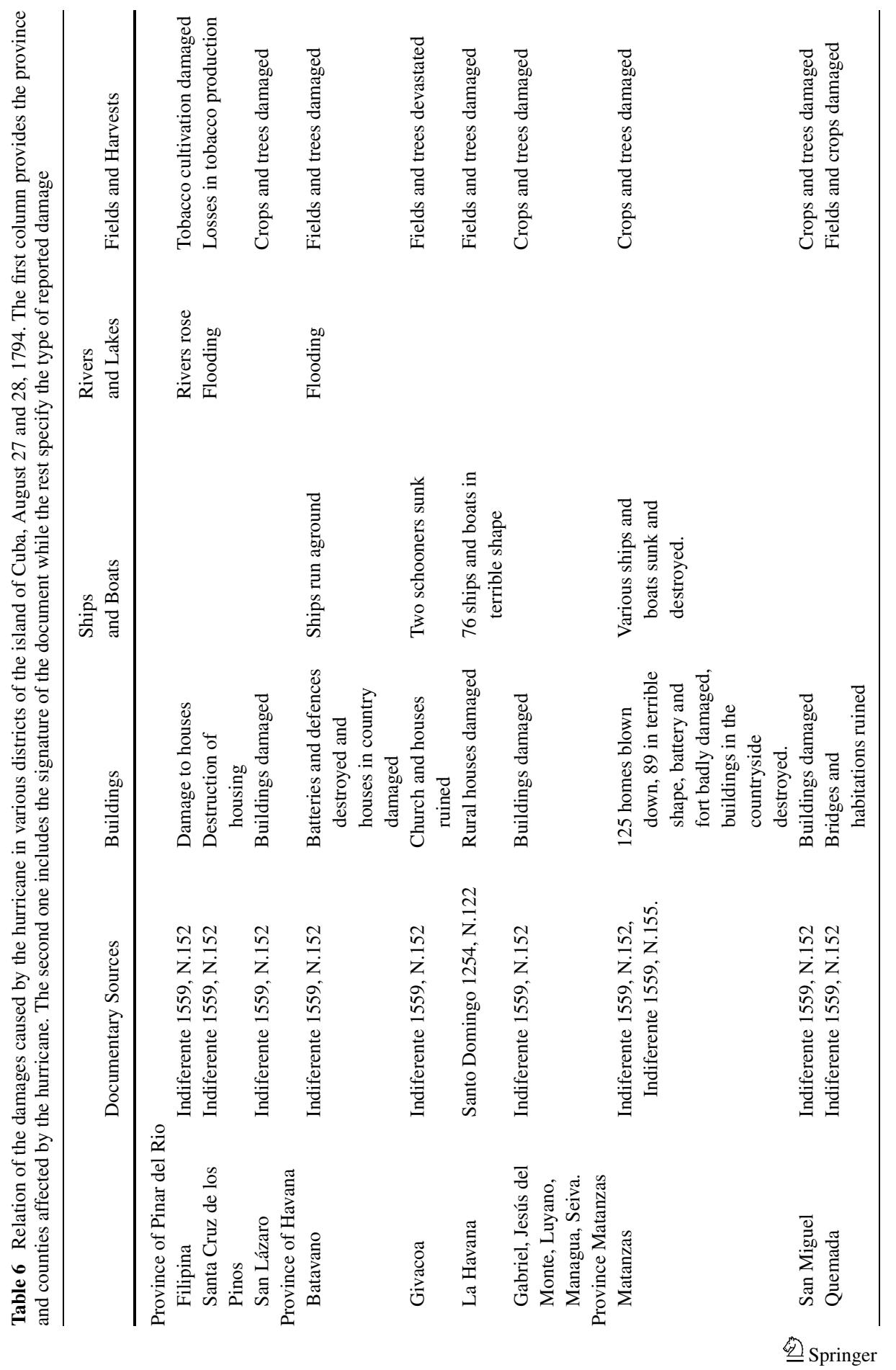




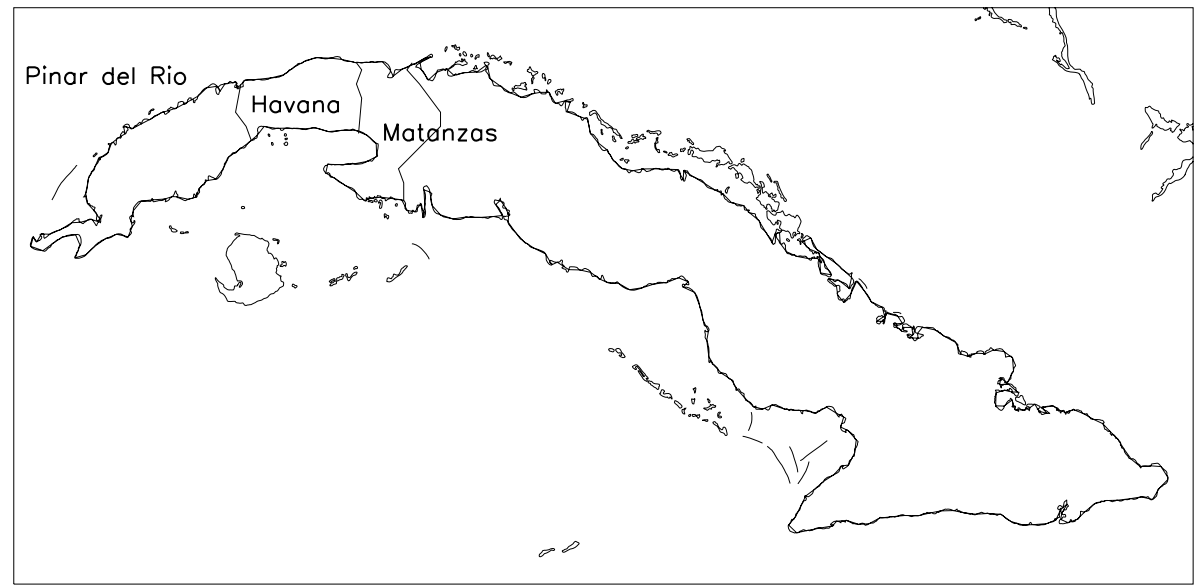

Fig. 4 Cuban Provinces affected by the hurricane of the 27th and 28th of August 1794. Pinar del Río counties: Filipina, Santa Cruz de los Pinos, and San Lázaro. Havana counties: Batavano, Givacoa, Gabriel, Jesús del Monte, Luyano, Managua, and Seiva. Matanzas county: San Miguel
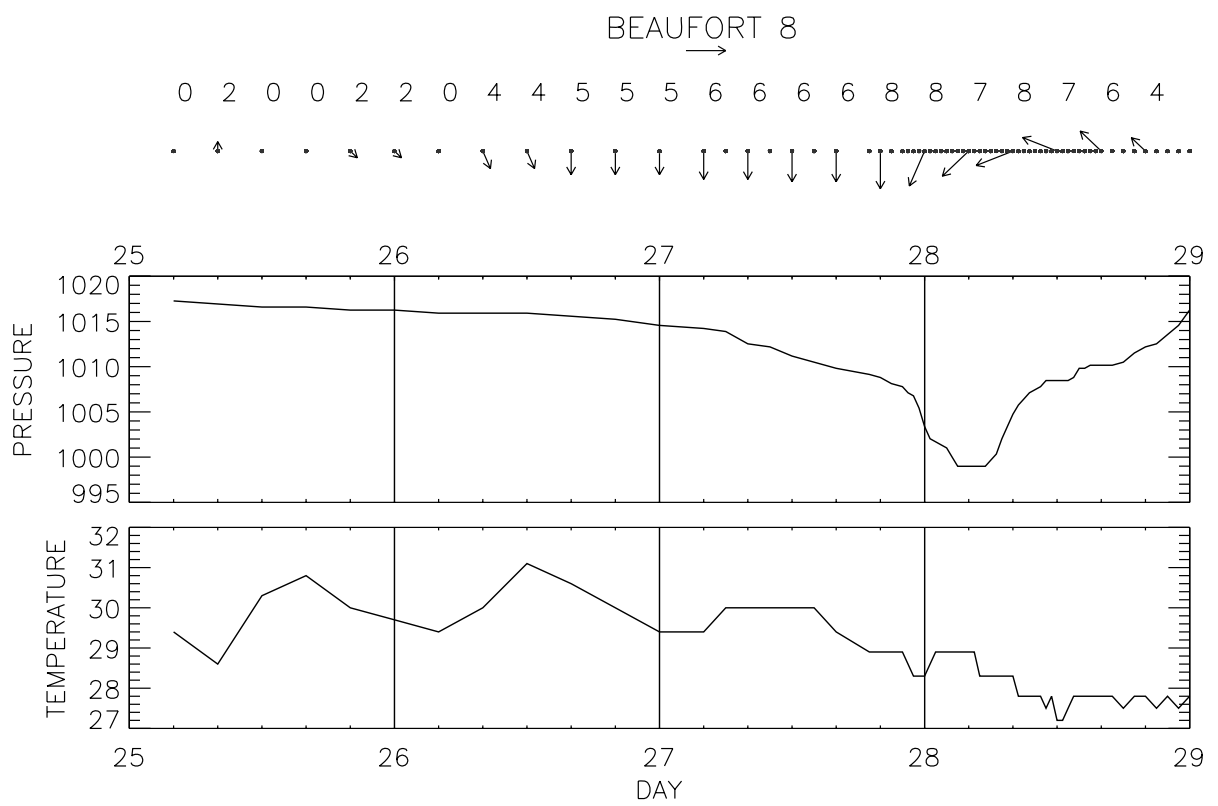

Fig. 5 Meteorological observations made by captain Tomás de Ugarte in Havana during the hurricane of August 27th-28th, 1794. Wind strength values are in Beaufort scale. The arrows show the reported direction. Pressure is in $\mathrm{hPa}$ and temperature in Celsius

in the observatory). Although rainfall is not a parameter used in Saffir-Simpson scale, the description of "heavy rain" until 10:30 of the 28th confirms that the three Cuban provinces with description of the hurricane were probably inside the eyewall (where the most intense precipitation occurs), or inside the outer (feeder) bands where convective precipitation occurs. Minimum pressure: surface pressure data are available only from the Havana observatory. The lowest pressure measured (Fig. 5) was 29.50 inches $\mathrm{Hg}(999 \mathrm{hPa})$ recorded between 3:00 Springer 


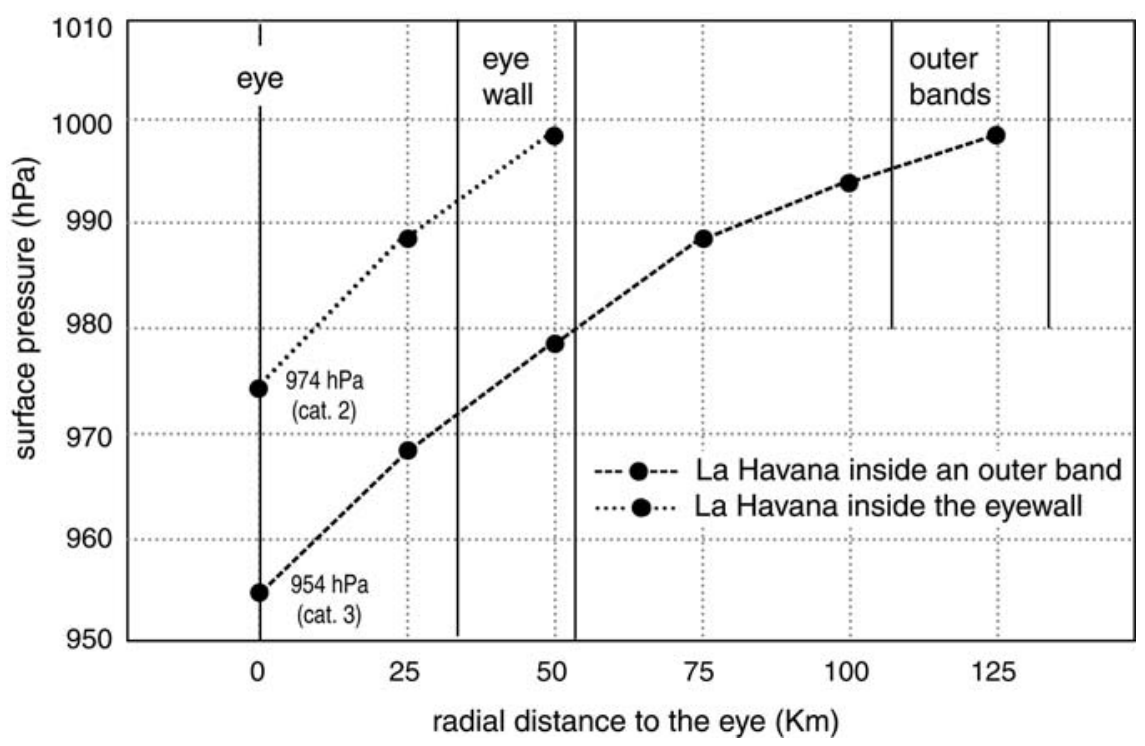

Fig. 6 Estimation of the surface pressure in the eye of the storm for two possible locations in Havana according to the $\mathrm{Zu}$ et al. model. See the text for details

to 5:30 on 28th August. If the pressure value of 29.50 inches is correct, then this equates to tropical storm force using the new wind-pressure relationship developed by Landsea et al. (2004). However, the area of minimum pressure (close to the hurricane eye) could have been placed more distant from Havana observatory. It is difficult to estimate the minimum pressure of a hurricane with pressure observations in a single place, but this can be done using typical values of radial pressure gradients based on modelling studies. In a numerical simulation of the hurricane Bonnie (1998), Zhu et al. (2004) calculated a radial gradient of pressure of $60 \mathrm{ba} / \mathrm{km}$ from the eye until $25 \mathrm{~km}, 40 \mathrm{ba} / \mathrm{km}$ from 25 to $75 \mathrm{~km}$ and $20 \mathrm{ba} / \mathrm{km}$ from 75 to $125 \mathrm{~km}$. Using these values we have estimated surface pressure in the eye for two possible locations in Havana (inside the eyewall or inside the feeder bands), as suggested in wind and precipitation observations. Figure 6 displays this estimation. If Havana had been placed in the eyewall, the minimum pressure would have been of $974 \mathrm{hPa}$ (category 2 in SS scale), while if it had been in the outer bands the minimum pressure would have been of $954 \mathrm{hPa}$ (category 3 in SS scale). The degree of damage can be used as a parameter with which to check the two possible locations and to estimate the cyclone's intensity. The Saffir-Simpson scale describes the damage associated to modern hurricanes, mainly describing damage to buildings and vegetation. It is not easy, however, to extrapolate the scale to 18th century buildings. Nevertheless, there are descriptions in Table 6 that could indicate strong intensity: destruction of houses in Santa Cruz de los Pinos and, especially, church and houses ruined in Givacoa, now Jibacoa. Although we have not found a particular reference to Givacoa church in Spanish archives, it must have been a stone building. According to Weiss (1985) "the basic building material in Cuba during the eighteenth century was stone", so the wind in the Jibacoa area must have been very strong, (possibly due to the proximity to the eyewall). Havana only had "rural houses" and some tree damage, which is more consistent with a location in the feeder bands than in the eyewall.

In conclusion, although there are significant uncertainties in the assessment of damage in historical times, the hurricane that occurred in August 27-28, 1794 was probably a major 
event (category 3 or higher) with the highest intensity in the Jibacoa area, located nearer to the storm center.

\section{Conclusions}

The cases in this paper show that the documents kept in the Spanish archives are extremely useful for analyzing the behaviour of past hurricanes. In particular, they can:

- Identify previously unreported hurricanes, such as cases 3 and 4.

- Provide precise dating for hurricanes previously identified, such as in case 1.

- Help to define better the area affected by a given hurricane, such as in cases 2 and 5. This is especially interesting when trying to provide accurate hurricane trajectories.

- Contribute to a better assessment of the hurricane intensity, by providing detailed descriptions of the impacts, such as in cases 1, 3, 4 and 5 .

- Help to evaluate other meteorological circumstances, as in case 2 with the Nortes spells.

They also show some of the difficulties associated with searching the archives. Thus, case 1 illustrates how reports of the same hurricane can be in different sections, the major division in the archive, and in several documents. Even more problematic, reports of storm effects may appear many years after the storm, as is the case for the 1605 hurricane, with reports dating between 1606 and 1634 (Table 3).

Finally, it is evident that primary sources provide more detailed and reliable results than secondary sources. This can be seen in cases 1 and 2, through a comparison between direct and indirect testimonies.

Acknowledgements This paper has been partially funded by the Spanish Ministry of Science and Technology (grant number REN2002-3984-E) and by MAPFRE Foundation. Mike Chenoweth and two anonymous reviewers provided extremely helpful comments, which we believe have improved substantially the original manuscript. Dennis Wheeler kindly corrected the final version of the manuscript.

\section{References}

Casas B de las (1552) Apologética Historia Sumaria. Universidad Nacional Autónoma de México. Instituto de investigaciones históricas. México (version edited in 1967)

Chenoweth M (2003) The 18th century climate of Jamaica. American Philosophical Society, Philadelphia, p 153

Chenoweth M (2006). Reassessment of historical Atlantic tropical cyclones. Climatic Change 76:169-240

du Tetre JB(1667) Histoire genérale des Antilles habitées par les Français. Paris

Fernández de Oviedo G (1535) Historia general y natural de las Indias. Ediciones Atlas, Madrid (Version edited in 1992)

Fernández-Partagás J, Díaz HF (1996) Atlantic hurricanes in the second half of the nineteenth century. Bull Amer Meteorol Soc 77:2899-2906

Fernández de Castro (1871) Estudio sobre los huracanes ocurridos en la Isla de Cuba. Madrid

García RR, Díaz HF, García Herrera R, Eischeid J, Prieto MR, Hernández E, Gimeno L, Rubio F, Bascary AM (2001) Atmospheric circulation changes in the tropical Pacific inferred from the voyages of the Manila Galleon in the 16th-18th centuries. Bull Amer Meteorol Soc 82(11):2435-2456

García Herrera R, Rubio F, Wheleer D, Hernández E, Prieto MR, Gimeno L (2004) The use of Spanish and British documentary sources in the investigation of Atlantic hurricanes in historical times. In: Murnane R, Liu K (eds) Hurricanes: present and past. Columbia University Press, New York, pp 149-176

Garcia-Herrera R, Gimeno L, Ribera P, Hernández E (2005a) New records of Atlantic hurricanes from Spanish documentary sources. Journal Geophys Research Atmospheres, doi: 10.1029/2004JD005272 
García-Herrera R, Können G, Wheeler D, Prieto MR, Jones P, Koek F (2005b) A climatological database for the world's oceans 1750-1854. Climatic Change 73:1-12, doi: 10-1007/s1058-005-6952-6

Landsea CW, Franklin JL, McAdie CJ, Beven II JL, Gross JM, Pasch RJ, Rappaport EN, Dunion JP, Dodge PP (2004) A re-analysis of Hurricane Andrew's (1992) intensity. Bull Amer Meteor Soc 85:1699-1712

Millás JC (1968) Hurricanes of the Caribbean and adjacent regions, 1492-1800. Academy of the Arts and Sciences of the Americas, Miami, p 326

Ortiz F (1984) El huracán. Su mitología y sus símbolos. Fondo de Cultura Económica. México, p 866

Poey A (1862) Table chronologique de quatre cents ciclones (depuis 1493 jusqu'en 1855). Paris

Vines B(1895) Investigaciones relatives a la circulacion y traslaction ciclonica en los Huracanes de las Antillas. Havana

Weiss JE (1985) La arquitectura colonial cubana. Siglo XVIII. Editorial Pueblo y Educación. Habana, p 342

Zhu T, Zhang DL, Weng F (2004) Numerical simulation of Hurricane Bonnie. Part I: Eyewall evolution and intensity changes. Mon Wea Rev 132:225-241 